NBER WORKING PAPER SERIES

\title{
SCHOOL-TO-CAREER AND POST-SECONDARY EDUCATION: EVIDENCE FROM THE PHILADELPHIA EDUCATIONAL LONGITUDINAL STUDY
}

\author{
Frank F. Furstenberg \\ David Neumark \\ Working Paper 11260 \\ http://www.nber.org/papers/w11260
NATIONAL BUREAU OF ECONOMIC RESEARCH
1050 Massachusetts Avenue
Cambridge, MA 02138
March 2005

We are grateful to Adena Galinsky for outstanding research assistance, and to Joshua Haimson and Thomas

Bailey for helpful comments. This paper was prepared for the Russell Sage Foundation's Conference on School-to-Work Transitions and School-to-Work Programs, New York, May 2004.The views expressed herein are those of the author(s) and do not necessarily reflect the views of the National Bureau of Economic Research.

(C)2005 by Frank F. Furstenberg and David Neumark. All rights reserved. Short sections of text, not to exceed two paragraphs, may be quoted without explicit permission provided that full credit, including () notice, is given to the source. 
School-to-Career and Post-Secondary Education: Evidence from the Philadelphia Educational Longitudinal Study

Frank F. Furstenberg and David Neumark

NBER Working Paper No. 11260

March 2005

JEL No. I28, J24

\begin{abstract}
$\underline{\text { ABSTRACT }}$
We study a set of programs implemented in Philadelphia high schools that focus on boosting post-secondary enrollment. These programs are less career oriented than traditional school-towork programs, but are consistent with the broadening of the goals of school-to-work to emphasize post-secondary education. The Philadelphia Longitudinal Educational Study (PELS) data set that we examine contains an unusually large amount of information on individuals prior to placement in STC programs. We use the detailed information in the PELS to study the process of selection into these programs and to examine their impact on a set of mainly schooling-related outcomes during and after high school, although we also consider their impact on non-academic outcomes. The data point to positive effects of these programs on high school graduation and on both academic and non-academic awards in high school, and similar negative effects on dropping out of high school. The results also suggest positive effects on aspirations for higher education and on college attendance. In addition, there is some evidence that these programs are more effective in increasing college attendance and aspirations among at-risk youths.

Frank F. Furstenberg, Jr.

Department of Sociology

University of Pennsylvania

3718 Locust Walk

Philadelphia, PA 19104

fff@sas.upenn.edu

David Neumark

Public Policy Institute of California

500 Washington Street, Suite 800

San Francisco, CA 94111

Institute of Business and Economic Research, UC-Berkeley

and NBER

neumark@ppic.org
\end{abstract}




\section{Introduction}

School-to-career (STC) programs implement specialized efforts to provide students with career information and education during the high school years to enhance their long-term prospects of educational attainment and labor market success, sometimes for sub-groups of the population that are less advantaged and would be less likely to attend four-year post-secondary institutions in the absence of these programs. In this paper, we study a set of programs implemented in Philadelphia high schools that focus on boosting post-secondary enrollment. These programs are less career oriented than traditional school-to-work programs. But consistent with the broadening of goals of these programs with the STWOA-in particular an increased emphasis on post-secondary education—we treat these programs meant to encourage post-secondary education as part and parcel of STC efforts. ${ }^{1}$

In general, there have been and continue to be two critical challenges to testing the presumed benefits of STC programs. First, there have been few data sets that collect extensive information on the high school years including participation in STC programs, and track youths through the school-to-career transition. Second, estimating the effects of STC programs confronts serious problems of selection, as STC programs may recruit the most promising or career-oriented students or such students may choose to participate in such programs, making the programs appear more effective than they are. Alternatively, there may be negative selection if students enter STC programs because they are encountering difficulties likely to hinder the school-to-career transition.

The Philadelphia Longitudinal Educational Study (PELS) data set that we examine in this paper contains an unusually large amount of information on individuals prior to placement in

\footnotetext{
${ }^{1}$ Indeed, the replacement of the "school-to-work" label with the "school-to-career" label in many states also reflects the broadening of goals to emphasize post-secondary education and its role in furthering career development.
} 
STC programs. Our analysis will compare students involved in STC programs with nonparticipants, among students who attend public high schools in Philadelphia. We use the detailed information in PELS to study the process of selection into these programs and to examine their impact on a set of mainly schooling-related outcomes during and after high school, although we also consider their impact on non-academic outcomes. This data set permits us to explore processes that lead to participation in STC, as well as to estimate the effects of STC programs taking account of sources of selection of the participants.

\section{Policy Background}

The 1994 Federal School-to-Work Opportunities Act (STWOA) provided more than \$1.5 billion for increased STC activities in the country's public schools. The STWOA was motivated by a concern among policymakers and researchers that school-to-career transitions of youths in the United States entail too much joblessness, job instability, and employment in dead-end jobs (U.S. General Accounting Office, 1990). It aimed to help young people develop the skills to succeed in high school and to make a successful transition to post-secondary education or into good jobs in the labor market (Office of Technology Assessment, 1995). However, after its initial five years the STWOA was not re-authorized, and many states have had to face the question of whether to step in and restore the lost federal funds, and at what level (see Schmidt, 2001).

Research evaluating the effectiveness of STC is also important in the broader policy context. In the late 1990s, STC programs had become an integral part of high school education in many states, spurred by the STWOA. But as reflected in the No Child Left Behind Act of 2001 (NCLB), educational reform now focuses largely on test-related outcomes measured via standardized testing in grades K-12. Another important perspective on educational quality, 
however, concerns the link between education and labor market success. There is no reason to believe that a focus on testing encompasses all of what schools do to prepare students for the transition beyond the high school years. For all students, the provision of information about careers, tools to make decisions about further education and careers, and assistance in developing and meeting educational goals, seem important complements to the academic component of education. For disadvantaged students attending inner-city schools, STC programs may not only boost academic skills and motivations, but they may also place students in a context where teachers and peers alike subscribe to the desirability and feasibility of attending college, differentiating them from the large number of students who will either drop out or go no further than high school graduation. Thus, without prejudging the outcome, there is good reason to keep STC research "on the table" in the context of broader issues of educational reform.

\section{Literature Review and Conceptual Framework}

\section{Conceptual Framework}

Our interest in this paper is in identifying the causal effects of participation in STC on a series of mainly academic and but also some non-academic outcomes relating to the school-tocareer transition: high school dropout and graduation; post-secondary enrollment; future educational objectives; and employment. Unbiased estimation of program effects from simple comparisons of outcomes between participants and non-participants requires that participants and non-participants be alike with respect to anything that influences the outcome, except for their participation in STC. However, we expect participants and non-participants to differ in some important demographic and academic characteristics determining eligibility for participation in a program or self-selection of participants; either one of these generates biases that must accounted for before we can assess the program impacts. 
The first line of defense against differences between participants and non-participants is to introduce an extensive set of controls for the factors that might be correlated with STC participation and also affect the dependent variables. ${ }^{2}$ Of course, we cannot be certain that adding a given set of proxy variables eliminates the endogenous selection problem. But comparing the estimated coefficients of STC participation with and without a detailed set of proxy variables can help to gauge whether biases from remaining unobservables are likely. Specifically, if the inclusion of the detailed proxy variables has little or no impact on the estimates, then because their inclusion reduces the bias from endogenous selection, it is arguably less plausible that remaining unobservables generate a correlation between STC participation and the outcomes we study (see Wooldridge, 2002).

The PELS offers a detailed set of control variables. In addition to fairly typical demographic controls, it includes detailed measures of family background and prior measures of academic achievement, including test scores going back to $2^{\text {nd }}$ grade. Perhaps more importantly, the PELS also includes a potentially compelling set of proxy variables for uncovering the causal effects of STC on schooling-related outcomes_-in particular, future educational expectations and aspirations regarding higher education, measured prior to STC participation. These expectations and aspirations variables should capture a good deal of the information individuals possess about their own education-related goals and aptitudes on the basis of which they might select into the programs we study. That is, it is plausible that any unobservables underlying the endogenous selection ought to be reflected in the reported expectations or aspirations, at least insofar as these are good or "efficient" statistical forecasts of later behavior so that subsequent deviations of

\footnotetext{
${ }^{2}$ There are other statistical techniques that in other contexts can be used to address endogenous selection. Random assignment is not available in this case. Instrumental variables estimation requires an exogenous variable that influences individual program participation but not the individual outcomes of interest. No obvious instrument exists in this context. Finally, longitudinal data on outcomes and participants before and after participation is not applicable in studying STC, because the object of study is the effects of a program on individuals' first labor market experiences, or on further school enrollment of those already enrolled.
} 
actual from expected behavior are random. In addition, the educational expectations and aspirations may not have any independent effects on outcomes net of the unobserved propensities for post-high school enrollment and other schooling-related outcomes for which they are proxies. Formally, these are the two conditions for a proxy variable to eliminate bias due to selection.

There is an intuitive explanation of why these expectations data may solve the endogenous selection problem. Prior to participating in STC, students are asked about their posthigh school expectations and aspirations. Some then participate in STC and some do not, and their post-high school behavior is subsequently observed. If, for example, conditional on educational expectations, STC participants are more likely to be enrolled in college after leaving high school, then it seems sensible to infer a causal effect of STC, because the expectations questions should control for remaining unobservables associated with post-high school educational outcomes.

Existing Research

A 1994 report of the National Center for Research in Vocational Education (NCRVE) summarized prior research on STC programs (Stern, et al., 1995). This compendium provides little persuasive evidence of positive impacts of STC programs on subsequent school and adult labor market outcomes. First, many of the studies do not construct a reasonable comparison group, let alone consider the problem of selection into the program on the basis of unobserved characteristics that might be correlated with outcomes. Second, even those studies that attempt to construct a good comparison group find few beneficial effects. Finally, some of the evidence suggests that STC programs may discourage post-secondary education.

A subsequent NCRVE report (Urquiola, et al., 1997) provides an update. Reflecting the 
still scant progress toward successful evaluations of STC programs, it focuses on implementation issues, and only a short chapter reviews a few new studies that grapple more seriously with inferring causal effects. Similarly, the national evaluation of the STWOA by Mathematica, Inc., also focuses on implementation (Hershey, et al., 1999).

Reinforcing this view of the existing evidence, a recent survey of published academic research on STC across the United States supports the claim that little progress has been made in estimating the causal effects of STC programs (Hughes, et al., 2001). However, one exception is the recent, ongoing evaluation of career academies by MDRC (Kemple and Snipes, 2000; Kemple, 2001; Kemple, 2004). This study is based on random assignment of students to career academies, as participants were chosen randomly from applicants, with participants and nonparticipants followed. The evaluation one year after the scheduled completion of high school found no impact on high school graduation rates, post-secondary education, or employment (Kemple, 2001). ${ }^{3}$ On the other hand, more recent studies of later data from this experiment point to increased earnings for men, at the possible cost of reduced schooling (Kemple, 2003).

Finally, recent research by Neumark and Rothstein (2003) uses the new National Longitudinal Survey of Youth (NLSY97) to study the effects of high school students' participation in a variety of STC programs. The NLSY97 is the first large-scale data set to include detailed information on participation in STC programs, and its richness also provides a number of approaches to estimating causal effects, including information on schooling (and work) expectations, although in less detail than in the PELS. The NLSY97 results indicate that participation in school enterprises boosts post-secondary college enrollments, and participation in coop programs and internships/apprenticeships boosts post-secondary employment.

\footnotetext{
${ }^{3}$ Comprehensive studies of local STC efforts in two states that developed extensive STC systems in response to the STWOA-Michigan and California-also failed to uncover compelling evidence on the effectiveness of STC (Neumark and Allen, 2003; Neumark, 2004).
} 
This last research is complementary to our analysis. However, the PELS differs in four important ways from the NLSY97. First, the nature of the programs covered is quite different, with those in the PELS consisting of a variety of mechanisms of support to boost post-secondary enrollment, with less of a career focus. Second, because the focus is on a single school district, there is greater uniformity in the types of programs in which sample members participate. Third, the more detailed look at a large urban school district provides important information on what STC can provide in such a setting. And fourth, the PELS offers important advantages in terms of data on both pre-program differences and on outcomes, in part because of links to administrative data files described in the next section.

\section{Research Design}

\section{PELS}

The Philadelphia Educational Longitudinal Study (PELS) follows a ten-percent sample of students (approximately 2000 students) in the Philadelphia School District, beginning in the $8^{\text {th }}$ grade. The data set includes school record information and test scores going back to the $2^{\text {nd }}$ grade (for those in the school system at the time) and parent interviews (which were not used in this paper). We also augmented the data with administrative records from the criminal justice system, birth records, and unemployment insurance, outcomes that will be examined in future analyses of the PELS.

The survey began in 1996, surveying $8^{\text {th }}$ graders about the $1995-1996$ school year during the summer of 1996 . Wave 2 was carried out during the $9^{\text {th }}$ grade academic year. The next four waves were carried out in the summer after grades 9-12, covering the previous academic year. No survey was done in 2001-2002, and a $7^{\text {th }}$ wave covering 2003-2004 has just been completed and will be used in future analysis along with the administrative information. 
For purposes of the present analysis, we are able to follow students through Wave 6, by which time most would have graduated from high school (unless they dropped out) and matriculated into college or entered the labor force or the military. A small portion of the sample still remained in school or were neither in school nor employed.

\section{Sample Attrition}

Because of the flux in the school population, it is not easy to measure sample attrition, especially in the beginning of the study. A substantial number of the approximately 2000 students selected in the original sample did not attend any public high school and were dropped from the study. Conversely, a sizable number of students entered the $9^{\text {th }}$ grade who had not previously been in the Philadelphia School District because they moved in from outside the District or switched from private to public schools. Therefore, we measure sample attrition from Wave 3, the sample of 1561 that was selected from the rolls of the $9^{\text {th }}$ grade attendees. About two-thirds of those students had been interviewed in Wave 1 and the remaining third were added to the sample at Waves 2 or 3. Of those students interviewed by Wave 3, we managed to reinterview slightly more than 75 percent at Wave 6 , a respectable response rate for a sample in which we relied on telephone interviews. (See Appendix Table A1 for detailed information on entry into the sample and sample attrition.) In fact, our true response rate is probably somewhat higher since an unknown portion of the students moved out of the city or switched to private or parochial schools and would not have been eligible for follow up. We had only limited success in tracking students who moved from the District to other localities. ${ }^{4}$

STC Programs in the PELS

There are a variety of STC-related programs in which students in the PELS can report

\footnotetext{
${ }^{4}$ Where the young adult is not interviewed because he or she could be reached after 20 or more attempts, we collect information on schooling and work from a parent in order not to lose PELS outcome data on participants. However, the parent did not receive the full survey, and those observations are therefore not used in this paper.
} 
participation in Waves 3-5. Most are not traditional school-to-work programs but rather efforts to provide academic support, counseling, role models, and career guidance to students who might not normally get such advice from teachers or family members, as the vast majority of students attending the public schools in our sample do not come from families with a college-educated parent. Over the past decade or so, the School District, with support largely from private funders, has established an array of programs to motivate students to get post-secondary training or education. Few of the existing programs actually encourage students to enter the labor force immediately upon high school graduation. In referring to "school-to-career" programs, then, we are really examining efforts that promote college attendance or some alternative form of postsecondary education. The implicit premise of the STC programs that we examine in our analysis is that the best way to help students achieve socioeconomic success may be to expose them to careers (and presumably the benefits thereof) that come from post-secondary education.

Many of the programs are quite small and they vary considerably in their intensity and comprehensiveness. We will consider the high degree of heterogeneity in the analysis that follows. But virtually all of the programs that we have identified share a common set of objectives: reinforcing careers objectives, exposing students to knowledge and requirements to enter careers, providing role models and mentors, exposing students to peers that share their ambitions and expectations, and helping students to garner resources to make the transition to higher education. These programs, and brief descriptions, are displayed in Table 1.

Appendix Table A2 provides information on participation for each of the STC programs. With the exception of College Access, the numbers for the programs are quite small, and among the others only exceed one percent of the sample for Academics Plus and PRIME; but over onehalf of the sample reported in Waves 3, 4, or 5 that they had been involved in at least one STC 
program. On average, the exposure to such programs was 1.7 years, if we consider participation reported in one year to imply program participation over the year. Participation was higher at the beginning and toward the end of the high school years, suggesting that the programs may have initially aimed at providing orientation to the future and toward the end of high school helped to prepare students for the transition to college, further training, or employment.

As might be expected, when we restricted our analysis to the subsample of those students who responded to all waves of the study (approximately half of the sample), participation in STC's was slightly higher. About 60 percent had been involved in one or more of the programs, spending on average about two years in STC programs. (See Appendix Table A2.) Thus, we can detect a modest bias for the programs selecting more stable and committed students; alternatively, programs may have increased school attendance and thus led to a greater likelihood of responding to the survey. (In general, we had somewhat lower success in maintaining involvement in the survey among the students who dropped out or did not attend school on a regular basis.) In the analysis that follows, we shall examine separately all students and those students who participated in every wave in which STC information was collected to take account of this potential source of selectivity.

Based on the reports of a knowledgeable informant, we attempted to identify characteristics of the programs reported by students. It appears that many of the smaller programs were transitory efforts to promote access to higher education through exposing students to role models, exemplars, and contacts in the workplace, providing information about colleges and universities, offering mentoring and remedial services, and helping to identify sources of financial aid. Programs varied greatly in the type and mix of services. There was no single or consistent model that could be identified across the programs or even within established 
programs. The largest-scale program was College Access, which by-passed traditional high school counselors. It offered information to students about higher education in resource centers located in some schools and in the community. These centers provided information and assistance in filling out college applications, visits to nearby college campuses, and connections to sources of financial aid. College Access also helped students prepare for the SAT's. Many of the smaller programs provided similar types of aid though the mix varied, depending on the site.

The heterogeneity between (and within) programs makes it very difficult to determine just how much of what types of services were offered to particular students in the PELS sample. Hence it is difficult to match particular components of the programs to particular outcomes in the analysis that follows. Nonetheless, we can safely assume that students who participated in the array of programs listed in Appendix Table A2 received more encouragement to apply to college, more information about how and where to apply, more assistance in the application process, and more sponsorship in garnering financial aid, than non-participants.

\section{Outcome Measures}

The PELS data set is extremely rich, and it is not possible to analyze in a single paper all of the potential available outcomes. We have chosen to concentrate in this analysis on the most obvious measures of academic success or related behaviors that should be linked to exposure to an STC program: dropping out, high school graduation, attendance at community college or four year program, educational plans after graduation; and employment. Among the potential labor market outcomes that can be studied are: current employment and wages for those who stopped attending school and for all respondents in later waves, information on after-school and summer jobs, participation in the underground economy, criminal behavior, and employment and earnings information from the UI records. In the present analysis, we confine our analysis to a 
subset of such outcomes, and consider them only briefly, since many of the participants have only recently moved into the labor market. In subsequent research that draws on the data collected in the most recent wave of the study, we will examine more closely labor market and other behavioral outcomes.

\section{Control Variables and Proxies}

The PELS offers detailed control and proxy variables. Some of these come from the administrative records. The school record includes information on test scores, absences and suspensions, and assignments to special education. Our package of controls includes a series of standard demographic characteristics including gender, race, and ethnicity, family structure (two biological parents, stepfamily, single-parent, and other), and test scores prior to entering high school. In later analyses, we also control for students' educational aspirations and expectations at the time of the $8^{\text {th }}$ grade interview.

\section{Data Analyses}

The proposed empirical analyses are relatively straightforward statistically, a simplicity that is afforded by the rich data set. We first explore the differences between students who enter STC programs and those who do not in our sample. This provides a starting point for assessing the degree to which selectivity is operating in program participation. We then examine a series of models for the key outcomes of dropout, school completion, matriculation in college, teen childbearing, and other related behavioral outcomes. For each of the outcomes, we introduce a package of controls that takes account of the likely sources of selection that might account for differences between participants and non-participants in the STC programs. We expect that the specifications controlling for family characteristics and prior academic achievement will account for most of the pre-program differences between participants and non-participants. For models 
of schooling-related outcomes, we believe that the schooling expectations and aspirations measures will even more fully account for pre-program differences, and we therefore expect that these specifications will provide our best estimates of the effects of STC on these outcomes. We also examine whether the variation among the STC programs is large enough to suggest differences in the effectiveness of the programs in producing a given outcome.

One potential limitation of the schooling expectations variables is that they could to some extent be outcomes of the high school experience, including STC. To avoid this problem, we use information on work and schooling expectations recorded prior to STC participation.

Fortunately, the PELS asked many of these questions in Wave 1, so the "cleanest" approach is to use this Wave 1 information. However, one might object that responses from Wave 1, when respondents were only at the end of $8^{\text {th }}$ grade, are uninformative. To address this concern, we also examine the relationship between the expectations from Wave 1 and eventual outcomes, to see whether the early expectations predict realized behavior.

\section{Empirical Results}

\section{Descriptive Information on Participants and Non-Participants}

Descriptive information on many of the demographic characteristics, test scores, and other characteristics of the entire sample and participants in the STC's is displayed in Table 2. As we anticipated, the program participants differ in some important respects from the larger sample of PELS. But the differences in all cases are relatively modest. Participants are more likely to be female (.59 of participants vs. .54 in the total sample) and black. However, they are very close in terms of the share Latino, household structure, their distribution across types of school, and test scores. Participants do have somewhat higher educational aspirations, suggesting the importance of controlling for these aspirations and factors related to them. 
Overall, though, the figures in Table 2 reveal that the various differences between STC participants and non-participants do not invariably favor the STC participants in terms of predictors of academic success. And they also suggest that there are not sharp differences between participants and non-participants.

\section{High School Outcomes}

We begin our analysis of the effects of STC programs by examining their impact on an array of academic outcomes, and then move to non-academic outcomes where we might expect to find less pronounced impacts. We start by looking in Table 3 at the link between STC participation and dropout from high school. Virtually all the programs share the common goals of helping students to remain in school and to avoid dropout. The models first examine the overall effect of participation in any program, adding packages of related control factors (gender and race), family structure, and test scores in the first four models. Note that the sample becomes smaller when data on test scores are required. Consequently Model 3 is the same as Model 2, but estimated for the sample with non-missing test scores, to enhance comparability of the estimates upon including the test scores, in Model 4, which examines all of the controls simultaneously. Model 5 looks for effects by type of program, separating out the two larger programs, the small programs, and programs that had not been identified prior to the survey (“Other"). We also test in Model 5 for heterogeneity of program effects. Model 6 looks at the amount of program exposure rather than simply a dichotomous indicator for STC participation. Finally, we repeat the analysis for Models 4 and 6 including only participants who completed all the sample waves in which there was STC information.

Controlling only for gender and race in Model 1, we find that participation in an STC is associated with a statistically significant decline in dropout from high school. The coefficient 
barely changes as we add other controls, indicating that the result is robust to different model specifications. The magnitude of the estimated effect implies that participation in an STC program reduces the probability of dropping out by about five or six percentage points. Model 5 reveals that the effect is roughly the same for most of the programs, although in this instance the combined small programs seem to produce smaller results on dropout. We are not inclined to make too much of this difference in view of the relatively small sample size; moreover, we do not reject the restriction of equal program effects. Model 6 reveals that increased exposure to the programs is associated with a lower rate of dropout as we might expect given the other results; note here that we expect the coefficient to be smaller since the scale of the variable is increased. ${ }^{5}$

When we examine only the students who were in all of the waves, we find a significant program effect that is roughly the same magnitude as we found for the larger sample. This result suggests that the program impact operates similarly among this more selective sample in which there is a lower overall rate of dropout, providing further confirmation that the effect of the STC programs on reducing high school dropout is not driven by selective attrition that is related to STC participation.

The flip side of dropout is high school graduation. As might be expected from the previous table, we observe in Table 4 that the percentage that graduates from high school is significantly and sizably greater among the STC participants than the non-participants. Once again, this result is unaffected by controls for family structure. Controls for test scores (which also predict high school graduation) do reduce the overall effect size slightly; nonetheless, the association remains large and statistically significant. Moreover, it is just as large for the students who were in all of the survey waves - a further indication that the impact of the

\footnotetext{
${ }^{5}$ It would be of interest to study directly the effects of multiple years of exposure to specific programs, but as the estimates reveal, participation in individual programs is sufficiently low that the effects of individual programs are imprecisely estimated.
} 
programs is not spurious.

Note that the figures in Tables 3 and 4 suggest dropout rates under 10 percent by Wave 6 , and graduation rates near 80 percent. The low dropout percentage and high graduation percentage in large part reflect attrition from the sample by Wave 6 of those more likely to drop out and less likely to graduate. This is confirmed based on administrative data on dropping out and graduation that are available whether or not one is surveyed in wave 6. Without exception, these administrative data show that among those entering the PELS in an early wave, administrative dropout rates are lower and administrative graduation rates are higher for those respondents who had not attrited by wave $6 .{ }^{6}$ A further problem is highlighted by findings reported in Neild, et al. (n.d.); in particular, administrative dropout rates were higher for the sampling universe of the PELS than for those who were ever surveyed, suggesting that there was also selective inclusion in the sample based on a lower likelihood of dropping out. Thus, the mean dropout and graduation rates displayed in Tables 3 and 4 are not representative of either the surveyed population or the sample universe. However, an appendix explores the sensitivity to attrition bias of the estimates of the effects of STC participation for many of the outcomes we study, and the findings suggest that any such bias is negligible.

We also examined a series of other indicators of high school success such as grade progression, skipping classes, absences from school, and receipt of academic and non-academic awards in high school. In most instances, the same pattern shown for dropout and graduation recurs. Though the association with STC participation does not always reach statistical significance, with the exception of cut or skipped classes, the pattern is always in the direction of showing that STC participants fare better than non-participants. (See Appendix Table A3).

\footnotetext{
${ }^{6}$ On the other hand, as of wave 6 the administrative and self-reported data show similar dropout rates and similar graduation rates, and regressions using the administrative data on dropout and graduation yield quite similar results to those in Tables 3 and 4 based on the self-reported data.
} 
More specifically, STC participation has a negative and significant effect on the probability of failing to progress, and positive and significant effects on the probabilities of receipt of both academic and non-academic awards. Thus, it appears that the participants do indeed receive the kind of reinforcement for investing in school that might be predicted from involvement in an STC program.

\section{Post-High School Education-Related Outcomes}

Now, we turn to some post-graduation outcomes to see if participation in an STC program is linked to changes that are maintained after completion of high school. We look first in Table 5 at educational aspirations for the years beyond high school. This is an important indicator of educational success because previous research shows that aspirations are associated with educational attainment. Furthermore, aspirations generally decline during the high school years, especially when students begin to encounter setbacks in school and face the difficult challenges of proceeding on to higher education. Therefore, as measured at Wave 6 , the year after expected high school graduation, educational aspirations tell us a lot about a student's orientation toward post-secondary schooling.

Large differences occur between STC participants and non-participants in their desires to continue their schooling. As is shown in Table 5, participants are much more likely to desire to aspire to higher educational levels. Controls only modestly reduce the overall difference between the program participants and non-participants. However, we should note that the participants in the small and varied programs ("combined small programs") do not follow the overall pattern of the larger programs or those in programs that were not otherwise classified. This disparity may be due to the fact that some of the smaller programs could stress a school-towork strategy rather than a school-to-higher education approach. Also in this case we find a 
smaller effect of STC participation for those who were in all of the sample waves compared with those who responded to the survey more intermittently; if persistence in the sample is also associated with higher educational aspirations, as seems plausible, this difference suggests that the educational aspiration results may be driven in part by selectivity.

We extend our analysis in Table 6 to examine a range of other measures of educational aspirations or expectations. The consistency of the findings is striking and is unaffected by the large package of controls that we included to account for selection. It would appear that designation and participation reinforce and perhaps strengthen future ambitions to complete college. From the current analysis, we cannot determine which elements of the program matter, but the strength of the findings, their consistency, and their robustness all indicate that STC programs galvanize students' ambitions to graduate from college.

In Table 7 we turn to actual post-secondary education. The results indicate that a significantly higher proportion of participants than non-participants enter a four-year college (a difference of about 10 percentage points). This association is strong with just the demographic controls and does not weaken when test score information is included in the model. This result holds up for the more selective sample of those who completed all waves of the study. Table 8 elaborates on this result by looking at variations of college attendance. It appears that STC participation works primarily to improve matriculation in college overall, as well as at four-year colleges specifically. When left to their own devices, students likely experience considerable difficulties in engaging in the planning that it takes to apply to college-particularly, perhaps, four-year programs_-gaining the support for trying to get admitted, and securing the funding to matriculate. Thus, it is not necessarily that the non-participants do not want to go on to higher education; rather, they may be less able to mobilize the resources to succeed in navigating the 
pathway to a college education.

It would be folly to claim that, in the analyses thus far, we have managed to control for all of the unmeasured differences that might account for the set of findings described in the series of academic outcomes described in the preceding tables. We took the further step of going back to the interview at Wave 1, before students entered high school, to add some additional controls dealing explicitly with academic ambitions. While our sample size shrinks because it does not include students added during the first two years of high school, the added controls provide a further safeguard against confusing selectivity with program effect. As it turns out, the students who participated in STC programs did not invariably have higher expectations and aspirations than the comparison group; see Table 9. Not surprisingly, then, the introduction of these controls did not change the findings reported in Tables 3 through 8 . As summarized in Table 10, the magnitudes of the program impacts were if anything reduced only slightly by adding controls for pre-existing ambitions, commitment to school, and perceived chances of graduating high school and completing college.

We also considered the possibility that the outcomes might have been linked to the type of high school that students attended: whether they went to a magnet school that required tests or screening to be admitted, or whether they attended one of the less selective neighborhood schools. The latter include neighborhood schools that the vast majority of students attend and vocational schools that are few in number. We consider evidence on the effects of different types of school by estimating the models with a main effect of STC participation, main effects for type of school, and interactions between the type of school and STC participation; the interactions identify differences in the effects of STC programs across school types. As shown in Table 11, the findings reveal that the effects of STC programs that we have documented thus 
far arise for the non-magnet schools, but tend not to appear for the far smaller number of magnetschool students. ${ }^{7}$ This probably occurs because the non-participants also are having their aspirations reinforced by peers in these more selective environments. The evidence is somewhat more mixed for the vocational schools. For high school outcomes (dropout and graduation), these students, like those in magnet schools, appear unaffected by STC participation. But for them the effects of STC participation on educational aspirations and college attendance (but not at four-year programs) is boosted relative to non-magnet, non-vocational students. On the other hand, only in Models 3 and 4, for educational aspirations and college attendance, are the differences in effects of STC programs significantly different by type of school.

In contrast to the previous table testing for differences in effects by type of school, we next examined differences in effects by type of student. In particular, we identified a number of variables that might be viewed as prior indicators of "at-risk" students, and estimated the models for each of the schooling outcomes adding the indicator, as well as an interaction between the indicator and STC participation. The at-risk indicators included: non-nuclear family; $8^{\text {th }}$ grade math scores below median; $8^{\text {th }}$ grade reading scores below median; aspires to less than 4-year college (as reported in Wave 1); and mother's education of high school or less. In these specifications, then, the main effect of STC participation ("any STC") measures the effect of the not-at-risk sample, and the estimated coefficient of the interaction captures the difference in the effect for those at-risk. The results are reported in Table 12. In general, there is some evidence of more beneficial effects of STC participation for at-risk students. In particular, STC participation appears to have larger effects on college attendance for those with low math scores (and insignificant effects for the others), and have larger effects on educational aspirations as

\footnotetext{
${ }^{7}$ For example, for dropout, the estimated overall effect of STC is -.087 , but for magnet school students the estimated interaction of .085 nearly completely offsets this.
} 
well as college attendance for those whose mother's have only a high school education or less (and again insignificant effects for the others). Finally, STC appears to reduce dropout more for those with low educational aspirations (at Wave 1). Thus, there is some evidence-although it is not overwhelming - suggesting that STC is more effective for at-risk youths.

Finally, we examined the impact of program participation on academic outcomes for males and females separately. Many of the point estimates of the effects were quite close by gender, and none were significantly different. However, the estimated impact of STC participation on high school graduation was considerably larger for males, by a factor of nearly two, providing a hint of more beneficial effects for them on this one outcome. (See Appendix Table A4.)

\section{Non-Academic Outcomes}

As noted earlier, the types of STC programs we study in the PELS are focused on postsecondary education. Nonetheless, we might expect to see some effects on non-academic outcomes. For example, there may be indirect effects on a set of behaviors that we would not necessarily expect to be directly driven by participation in an STC program, but that are associated with the academic outcomes that STC appears to promote. In addition, STC programs generally focus on careers more than education per se, so it is of interest to look at labor market outcomes.

We therefore looked at effects of STC participation on a number of labor market outcomes for those who had left high school, including employment (overall, for those not in college, and for those in college), earnings, and wages. ${ }^{8}$ There was very little if any evidence of program effects - at best a hint of positive employment effects for those not in college. Given

\footnotetext{
${ }^{8}$ Hours of employment cannot be studied because the skip pattern in the survey only elicits hours information for those with multiple jobs.
} 
that the STC programs we study appear to have focused on college attendance, these results are perhaps not surprising. However, future analysis that will draw on the final follow up (Wave 7), conducted two to three years after the date of expected high school graduation, to revisit the labor market and other non-schooling related effects of these STC programs. Very possibly, it was too early to detect labor market outcomes from the Wave 6 data we use in the present analysis. $^{9}$

\section{Summary and Conclusion}

Previous research on the impact of school-to-career programs has been mixed in part because of the nature of the programs, the populations that they serve, the design of the studies, and the types of analysis employed. Our study (and our results) most closely resemble the previous research by Neumark and Rothstein (2003), using data from the new 1997 National Longitudinal Survey of Youth. They found a strong association between participation in some STC programs and positive academic outcomes. Our data from a large and representative sample of Philadelphia high school students was collected annually from 1996 when a random sample was drawn of students at the end of the $8^{\text {th }}$ grade. It offers a richer set of controls including test scores and indicators of motivation prior to high school, and finds similar positive effects on academic outcomes_-in this case a wide array of such outcomes.

In particular, the data point to positive effects of these programs on high school graduation and on both academic and non-academic awards in high school, and similar negative

\footnotetext{
${ }^{9}$ While much of focus of existing research on STC is on schooling and employment outcomes, the PELS also elicits information on fertility and unprotected sexual activity and on criminal activity. If participation in STC increases the likelihood of high school graduation and strengthens academic goals, it might also increase the opportunity costs of teenage parenthood. Therefore, we also examined whether female STC participants were less likely to become pregnant or have a live birth by Wave 6. Although the estimates were in the direction of a reduced likelihood of pregnancy or live birth for participants, the estimated effects were generally not statistically significant. With regard to crime, convictions are extremely rare in this data set, perhaps because of the young ages of respondents, so all we can look at are arrests. For arrests, there is no evidence of a consistent pattern of STC effects. However, future analysis with the data from Wave 7 will provide a look at criminal activity further on, and using administrative records, which should be more informative.
} 
effects on dropping out of high school. The results also suggest positive effects on aspirations for higher education and on college attendance. In addition, there is some evidence that these programs are more effective in increasing college attendance and aspirations among at-risk youths.

The findings are generally quite robust and are only slightly attenuated by the introduction of factors that might be indicative of selection or "creaming effects." Some programs were more effective than others, but the variability of effects generally did not differ significantly, suggesting that at least the effects were almost invariably in the predicted direction. We did discover that the setting of the programs matter: the impact of the programs was generally greater in the neighborhood as opposed to the magnet schools. For the most part, the effects were similar for males and females though the impact on high school graduation may be more pronounced for males. Finally, there is some evidence that effects of the STC programs we study were greater for at-risk students, especially those whose mothers have at most a high school education.

However extensive the set of controls that are permitted by the PELS data set, we cannot rule out the possibility of other unmeasured sources of bias between the participants and nonparticipants. In future analysis, we shall explore the pathways by which effects operate such as through channeling students into more challenging programs, providing greater access to resources and services, and creating segregated peer environments of students more committed to going on to higher education.

Ultimately, there is a pressing need for more random assignment experiments in such programs. Given the fact that the programs do not seem simply to cream the more capable students, but rather to have beneficial effects (at least as far as we can tell in non-experimental 
data), the conditions are ripe for such experimentation. At the very least, we can say with some confidence that the results of our analysis suggest that greater experimentation is warranted. 


\section{Appendix: Attrition and Attrition Bias}

We have touched briefly on the potential effects of attrition bias with regard to presenting estimates for respondents in any of Waves 3-5 and those in all three waves. We also explored attrition more directly. The key concern is selective attrition that would bias the estimated effects of STC. For example, if among non-participants attrition is random, but among participants those with worse performance in high school tend to attrit, then the estimates would tend to be biased in the direction of positive effects of STC participation on education-related outcomes.

To explore whether there is attrition of this nature, Appendix Table A5 reports estimates of models for attrition by Wave 6 of those in any of Waves 3-5. The models include the same set of controls used in the previous models, but also interactions between STC participation and a number of variables thought to be associated with better or worse outcomes (test scores, living arrangements, whether the individual was held back a grade in earlier waves, and dropout as recorded in the administrative data). For many of the variables, the differentials in attrition rates associated with STC participation were not significant. However, for the interactions with held back a grade, the estimates are consistent with the type of selective attrition pattern outlined above, as those who were held back and participated in STC were much more likely to attrit. This type of attrition pattern suggests that the estimates of the beneficial effects of STC estimated earlier may be upward biased because of selective attrition.

Aside from including variables such as test scores and living arrangements as controls, we can go further in correcting the estimates for attrition bias based on these observable measures. In particular, to correct for attrition bias, we re-estimated models for some of the key outcomes, reweighting the observations to account for attrition associated with STC participation and being held back, dropping out, etc. What this reweighting does is restore the 
representativeness of the Wave 6 observations. For example, consider the attrition model in column (4) of Appendix Table A5, which looks at the relationship between being held back, STC participation, and attrition. Given that those held back who participated in STC attrit at a higher rate, the weight on observations on such individuals in Wave 6 is increased so that the representation of these individuals is the same as in the Wave 3-Wave 5 sample. We do this correction using the implied probabilities of attrition from the attrition model in column (4), as well as the model in column (5) that accounts for more predictors of attrition and their interactions with STC participation.

Appendix Table A6 reports the earlier uncorrected results, and then the results corrected for attrition using this method. Despite the non-random attrition, these results reveal that any bias from attrition is trivial. Although in each case the point estimate of the beneficial effect of STC participation falls (in absolute value), the changes in the estimated coefficients are minimal. Thus, these findings provide further confirmation that the STC programs we study in the PELS improved educational outcomes. 


\section{References}

Hershey, Alan M., Marsha K. Silverberg, and Joshua Haimson. 1999. "Expanding Options for Students: Report to Congress on the National Evaluation of School-to-Career Implementation.” Mathematica Policy Research, Inc., Princeton, New Jersey.

Hughes, Katherine L., Stephen F. Hamilton, and Robert J. Ivry. 2001. "School-to-Career:

Making a Difference in Education." Institute on Education and the Economy, Teachers College, Columbia University, New York, New York.

Kemple, James J. 2004. "Having an Impact on the Transition from School to Work: Evidence from Career Academies." Unpublished manuscript, Manpower Demonstration Research Corporation, New York, New York.

Kemple, James J. 2001. “Career Academies: Impacts on Students' Initial Transitions to PostSecondary Education and Employment.” Manpower Demonstration Research Corporation, New York, New York.

Kemple, James J., and Jason C. Snipes. 2000. "Career Academies: Impacts on Students' Engagement and Performance in High School.” Manpower Demonstration Research Corporation, New York, New York.

Neild, Ruth Curran, Scott Stoner-Eby, and Frank F. Furstenberg. n.d. "Connection Entrance and Departure: The Transition to Ninth Grade and High School Dropout.” Unpublished manuscript, University of Pennsylvania.

Neumark, David. 2004. "Evaluation of the Effectiveness of the School-to-Work Opportunities Act in California," Public Policy Institute of California Working Paper No. 2004.02.

Neumark, David, and Ann Allen. 2003. "What Do We Know About the Effects of School-toCareer? A Case Study of Michigan,” Journal of Vocational Education Research, Vol. 28, No. 1, pp. 59-84. 
Neumark, David, and Donna Rothstein. 2003. "School-to-Career Programs and Transitions to Employment and Higher Education,” Public Policy Institute of California Working Paper No. 2003.22.

Office of Technology Assessment, United States Congress. 1995. "Learning to Work: Making the Transition from School to Work.” Publication No. OTA-HER 637, U.S. Government Printing Office, Washington, D.C.

Schmidt, Tracy J. 2001. "Inside the State House: The People and Ideas that Shaped School-toCareer Legislation.” National Conference of State Legislatures, Washington, D.C.

Stern, David, Neal Finkelstein, James R. Stone, John Latting, and Carolyn Dornsife. 1995. School to Work: Research on Programs in the United States (Falmer Press: London and Washington).

Urquiola, Miguel, David Stern, Ilana Horn, Carolyn Dornsife, Bernadette Chi, Lea Williams, Donna Meritt, Katherine Hughes, and Thomas Bailey. 1997. "School to Work, College and Career: A Review of Policy, Practice, and Results, 1993-1997." National Center for Research in Vocational Education, University of California, Berkeley, California.

U.S. Department of Education. 2003. TRIO Home Page, Washington, D.C., n.d. (http://www.ed.gov/about/offices/list/ope/trio/index.html, retrieved September 15, 2003). U.S. General Accounting Office. 1990. "Preparing Noncollege Youth for Employment in the U.S. and Foreign Countries." Washington, D.C.

Wooldridge, Jeffrey M. 2002. Econometric Analysis of Cross Section and Panel Data (The MIT Press, Cambridge, Massachusetts). 
Table 1: STC Programs in the PELS

\begin{tabular}{|l|l|}
\hline Program & Description \\
\hline Academics Plus & $\begin{array}{l}\text { State licensed and accredited school that offers private instruction, tutoring, } \\
\text { summer school in a variety of advanced courses }\end{array}$ \\
\hline ASPIRA & $\begin{array}{l}\text { Develops leadership skills, educational endeavors, cultural awareness, and social } \\
\text { action among Puerto Rican and Latino students }\end{array}$ \\
\hline College Access & $\begin{array}{l}\text { Provides college readiness services, individual advising, financial aid and } \\
\text { scholarship assistance to low-income youth from the most disadvantaged areas of } \\
\text { the city, emphasizing those who would be the first in their family to attend college }\end{array}$ \\
\hline LASER & $\begin{array}{l}\text { Program to expose Philadelphia high school students to advanced science and } \\
\text { engineering }\end{array}$ \\
\hline Legacy & $\begin{array}{l}\text { Federal TRIO Program providing comprehensive services to disadvantaged or } \\
\text { disabled students to assist in pursuing post-secondary education }\end{array}$ \\
\hline Fhiladelphia & $\begin{array}{l}\text { Offers numerous programs to help disadvantaged Philadelphia teenagers excel in } \\
\text { their studies and prepare for college and careers }\end{array}$ \\
\hline PRIME & $\begin{array}{l}\text { Enhances minority student skills in mathematics, communications, and } \\
\text { engineering, through mentoring, math/science/engineering competitions, and } \\
\text { summer programs and internships before starting college }\end{array}$ \\
\hline $\begin{array}{l}\text { Say Yes to } \\
\text { Education }\end{array}$ & $\begin{array}{l}\text { Sponsors students from very disadvantaged backgrounds, providing educational } \\
\text { enrichment, tutoring and mentoring, counseling, and other resources, emphasizing } \\
\text { relationship with institution of higher education }\end{array}$ \\
\hline Upward Bound & $\begin{array}{l}\text { Focuses on high school students from low income families and families in which } \\
\text { parents have low education. Provides instruction in academic subjects, tutorial } \\
\text { services, mentoring programs, information on post-secondary education, assistance } \\
\text { in preparing for college entrance examinations, and work experiences to expose } \\
\text { students to careers for which post-secondary degrees are required }\end{array}$ \\
\hline $\begin{array}{l}\text { White-Williams } \\
\text { Scholars }\end{array}$ & $\begin{array}{l}\text { Program provides disadvantaged Philadelphia public high school students who } \\
\text { maintain good grades with modest monthly stipend and school-related expenses } \\
\text { such as test and college application fees }\end{array}$ \\
\hline For details on TR & program, see U.S. Department Of Education (2003), \\
\hline
\end{tabular}

For details on TRIO program, see U.S. Department of Education (2003). 
Table 2: Demographic Characteristics of STC Participants and Non-Participants, Sample in Any Wave with STC Information

\begin{tabular}{|c|c|c|c|c|c|c|c|c|c|c|c|c|c|}
\hline & \multicolumn{13}{|c|}{ Proportion of sample: } \\
\hline & & Female & Black & Latino & $\begin{array}{l}\text { Asian/ } \\
\text { Other }\end{array}$ & $\begin{array}{c}\text { Lives with } \\
\text { bio mother } \\
\text { only }\end{array}$ & $\begin{array}{l}\text { Lives with } \\
\text { one bio and } \\
\text { one step } \\
\text { parent }\end{array}$ & $\begin{array}{l}\text { Other living } \\
\text { arrangement }\end{array}$ & $\begin{array}{c}\text { Magnet } \\
\text { school }\end{array}$ & $\begin{array}{c}\text { Vocational } \\
\text { school }\end{array}$ & $\begin{array}{l}\text { Educational } \\
\text { aspirations 4- } \\
\text { year college } \\
\text { or higher }\end{array}$ & $\begin{array}{l}\text { Reading } \\
\text { test score } \\
\text { below } \\
\text { median }\end{array}$ & $\begin{array}{l}\text { Math test } \\
\text { score } \\
\text { below } \\
\text { median }\end{array}$ \\
\hline $\begin{array}{l}\text { Overall } \\
\text { sample }\end{array}$ & & .54 & .70 & .07 & .03 & .37 & .18 & .14 & .10 & .08 & .83 & .44 & .43 \\
\hline $\begin{array}{l}\text { STC } \\
\text { participants: }\end{array}$ & $\begin{array}{c}\text { Participation } \\
\text { rate } \\
\text { (number) }\end{array}$ & & & & & & Proportion i & roup among $\mathrm{p}$ & ticipants & & & & \\
\hline $\begin{array}{l}\text { Academics } \\
\text { Plus }\end{array}$ & $.033(56)$ & .59 & .91 & 0 & .02 & .50 & .09 & .16 & .13 & .04 & .93 & .43 & .57 \\
\hline ASPIRA & $.004(6)$ & .83 & .33 & .50 & 0 & .50 & .17 & 0 & .33 & 0 & 1 & .33 & 0 \\
\hline $\begin{array}{l}\text { College } \\
\text { Access }\end{array}$ & $.449(752)$ & .59 & .82 & .06 & .02 & .38 & .19 & .15 & .07 & .06 & .85 & .43 & .43 \\
\hline Laser & $.001(1)$ & 1 & 1 & 0 & 0 & 0 & 0 & 1 & 1 & 0 & 0 & 0 & 0 \\
\hline Legacy & $.004(7)$ & .86 & 1 & 0 & 0 & .57 & 0 & 0 & .14 & .14 & 1 & .50 & .67 \\
\hline $\begin{array}{l}\text { Philadelphia } \\
\text { Futures }\end{array}$ & $.005(9)$ & .44 & .89 & .11 & 0 & .44 & .22 & .22 & 0 & 0 & 1 & 0 & .40 \\
\hline PRIME & $.042(70)$ & .71 & .91 & .03 & .04 & .39 & .17 & .17 & .19 & .10 & .93 & .34 & .30 \\
\hline $\begin{array}{l}\text { Say Yes to } \\
\text { Education }\end{array}$ & $.001(2)$ & 0 & 1 & 0 & 0 & .50 & 0 & 0 & 0 & 0 & 1 & .50 & .50 \\
\hline $\begin{array}{l}\text { Upward } \\
\text { Bound }\end{array}$ & $.004(6)$ & 1 & 1 & 0 & 0 & .33 & .17 & 0 & 0 & 0 & 1 & .67 & 1 \\
\hline $\begin{array}{l}\text { White- } \\
\text { Williams } \\
\text { Scholars }\end{array}$ & $.011(18)$ & .83 & .89 & .05 & 0 & .50 & .17 & .17 & .06 & .06 & .80 & .30 & .36 \\
\hline Other & $.087(145)$ & .64 & .77 & .05 & .04 & .41 & .12 & .19 & .14 & .10 & .96 & .38 & .43 \\
\hline $\begin{array}{l}\text { Combined } \\
\text { small } \\
\text { programs } \\
\end{array}$ & $.026(43)$ & .74 & .88 & .09 & 0 & .51 & .12 & .14 & .12 & .05 & .86 & .38 & .46 \\
\hline $\begin{array}{l}\text { Any STC } \\
\text { participation }\end{array}$ & $.513(860)$ & .59 & .81 & .06 & .02 & .38 & .18 & .15 & .10 & .07 & .87 & .42 & .43 \\
\hline
\end{tabular}

There are 1675 observations in all columns except the last three, because of missing data. In the first row of the last two columns, the shares below the median are different from 0.5 because the medians are computed for the full sample of available test scores. The combined small programs include Aspira, Laser, Philadelphia Futures, Say Yes to Education, and White-Williams Scholars. 
Table 3: Effects of STC Participation on Dropping Out of High School by Wave 6

\begin{tabular}{|c|c|c|c|c|c|c|c|c|}
\hline & \multicolumn{6}{|c|}{ Sample in any waves with STC information } & \multicolumn{2}{|c|}{$\begin{array}{l}\text { Sample in all waves with } \\
\text { STC information }\end{array}$} \\
\hline & (1) & $(2)$ & (3) & (4) & $(5)$ & (6) & $(7)$ & $(8)$ \\
\hline Mean of dep. var. & \multicolumn{2}{|c|}{.088} & \multicolumn{4}{|c|}{.071} & \multicolumn{2}{|c|}{.054} \\
\hline Any STC & $\begin{array}{l}-.059 \\
(.019)\end{array}$ & $\begin{array}{l}-.059 \\
(.019) \\
\end{array}$ & $\begin{array}{l}-.066 \\
(.021) \\
\end{array}$ & $\begin{array}{l}-.061 \\
(.021) \\
\end{array}$ & $\cdots$ & $\ldots$ & $\begin{array}{l}-.058 \\
(.025) \\
\end{array}$ & $\cdots$ \\
\hline Academics Plus & $\ldots$ & $\ldots$ & $\cdots$ & $\ldots$ & $\begin{array}{l}-.050 \\
(.060) \\
\end{array}$ & $\cdots$ & $\ldots$ & $\cdots$ \\
\hline College Access & $\ldots$ & $\ldots$ & $\cdots$ & $\ldots$ & $\begin{array}{l}-.048 \\
(.021)\end{array}$ & $\cdots$ & $\ldots$ & $\cdots$ \\
\hline PRIME & .. & $\cdots$ & $\cdots$ & $\cdots$ & $\begin{array}{l}-.054 \\
(.047)\end{array}$ & $\cdots$ & $\cdots$ & $\cdots$ \\
\hline $\begin{array}{l}\text { Combined small } \\
\text { programs }\end{array}$ & $\cdots$ & $\cdots$ & $\cdots$ & $\cdots$ & $\begin{array}{l}-.004 \\
(.079)\end{array}$ & $\cdots$ & $\cdots$ & $\cdots$ \\
\hline Other & $\cdots$ & $\ldots$ & $\ldots$ & $\cdots$ & $\begin{array}{l}-.047 \\
(.033) \\
\end{array}$ & $\cdots$ & $\cdots$ & $\cdots$ \\
\hline $\begin{array}{l}\text { Test equality of STC } \\
\text { coefficients (p- } \\
\text { value) }\end{array}$ & $\cdots$ & $\cdots$ & $\cdots$ & $\cdots$ & .990 & $\cdots$ & $\cdots$ & $\cdots$ \\
\hline $\begin{array}{l}\text { Number of programs } \\
\text { x years }\end{array}$ & .. & $\ldots$ & $\cdots$ & $\cdots$ & $\cdots$ & $\begin{array}{r}-.025 \\
(.009) \\
\end{array}$ & $\cdots$ & $\begin{array}{r}-.018 \\
(.010) \\
\end{array}$ \\
\hline Female & $\begin{array}{l}-.006 \\
(.019)\end{array}$ & $\begin{array}{l}-.005 \\
(.019) \\
\end{array}$ & $\begin{array}{l}.008 \\
(.021)\end{array}$ & $\begin{array}{l}.010 \\
(.021) \\
\end{array}$ & $\begin{array}{l}.013 \\
(.021) \\
\end{array}$ & $\begin{array}{l}.010 \\
(.021)\end{array}$ & $\begin{array}{l}.028 \\
(.024)\end{array}$ & $\begin{array}{l}.027 \\
(.024)\end{array}$ \\
\hline Black & $\begin{array}{l}-.038 \\
(.024) \\
\end{array}$ & $\begin{array}{l}-.058 \\
(.025) \\
\end{array}$ & $\begin{array}{l}-.060 \\
(.028) \\
\end{array}$ & $\begin{array}{l}-.086 \\
(.029) \\
\end{array}$ & $\begin{array}{l}-.084 \\
(.029) \\
\end{array}$ & $\begin{array}{l}-.088 \\
(.029) \\
\end{array}$ & $\begin{array}{l}-.081 \\
(.032) \\
\end{array}$ & $\begin{array}{l}-.085 \\
(.032) \\
\end{array}$ \\
\hline Latino & $\begin{array}{l}.030 \\
(.043) \\
\end{array}$ & $\begin{array}{l}.011 \\
(.043) \\
\end{array}$ & $\begin{array}{l}.039 \\
(.048) \\
\end{array}$ & $\begin{array}{l}.015 \\
(.048) \\
\end{array}$ & $\begin{array}{l}.016 \\
(.048) \\
\end{array}$ & $\begin{array}{l}.011 \\
(.048) \\
\end{array}$ & $\begin{array}{l}.035 \\
(.069) \\
\end{array}$ & $\begin{array}{l}.027 \\
(.069) \\
\end{array}$ \\
\hline Asian/other & $\begin{array}{l}-.020 \\
(.057)\end{array}$ & $\begin{array}{l}-.015 \\
(.057)\end{array}$ & $\begin{array}{l}-.062 \\
(.064)\end{array}$ & $\begin{array}{l}-.058 \\
(.064)\end{array}$ & $\begin{array}{l}-.054 \\
(.064)\end{array}$ & $\begin{array}{l}-.055 \\
(.064)\end{array}$ & $\begin{array}{l}.009 \\
(.078)\end{array}$ & $\begin{array}{l}.014 \\
(.078)\end{array}$ \\
\hline $\begin{array}{l}\text { Lives with bio } \\
\text { mother only }\end{array}$ & $\cdots$ & $\begin{aligned} .034 \\
(.023) \\
\end{aligned}$ & $\begin{array}{l}.020 \\
(.025)\end{array}$ & $\begin{array}{l}.016 \\
(.025) \\
\end{array}$ & $\begin{array}{l}.020 \\
(.025)\end{array}$ & $\begin{array}{l}.020 \\
(.025) \\
\end{array}$ & $\begin{array}{l}-.001 \\
(.028) \\
\end{array}$ & $\begin{array}{l}.003 \\
(.028) \\
\end{array}$ \\
\hline $\begin{array}{l}\text { Lives with one bio } \\
\text { and one step parent }\end{array}$ & $\cdots$ & $\begin{array}{l}.079 \\
(.028)\end{array}$ & $\begin{array}{l}.039 \\
(.032)\end{array}$ & $\begin{array}{l}.034 \\
(.032)\end{array}$ & $\begin{array}{l}.034 \\
(.032)\end{array}$ & $\begin{array}{l}.033 \\
(.032)\end{array}$ & $\begin{array}{l}.053 \\
(.036)\end{array}$ & $\begin{array}{l}.054 \\
(.036)\end{array}$ \\
\hline $\begin{array}{l}\text { Other living } \\
\text { arrangement }\end{array}$ & .. & $\begin{array}{l}.104 \\
(.030) \\
\end{array}$ & $\begin{array}{l}.094 \\
(.034) \\
\end{array}$ & $\begin{array}{l}.081 \\
(.034) \\
\end{array}$ & $\begin{array}{l}.086 \\
(.034) \\
\end{array}$ & $\begin{array}{l}.084 \\
(.034) \\
\end{array}$ & $\begin{array}{c}.062 \\
(.038) \\
\end{array}$ & $\begin{array}{c}.066 \\
(.039) \\
\end{array}$ \\
\hline $\begin{array}{l}\text { Only non-missing } \\
\text { test scores }\end{array}$ & & & $\mathrm{X}$ & $\mathrm{X}$ & $\mathrm{X}$ & $\mathrm{X}$ & $\mathrm{X}$ & $\mathrm{X}$ \\
\hline $\begin{array}{l}\text { Reading test (1995) } \\
\cdot 10^{-2}\end{array}$ & $\cdots$ & .. & .. & $\begin{array}{l}-.108 \\
(.048) \\
\end{array}$ & $\begin{array}{l}-.109 \\
(.048) \\
\end{array}$ & $\begin{array}{l}-.107 \\
(.048) \\
\end{array}$ & $\begin{array}{l}-.097 \\
(.056) \\
\end{array}$ & $\begin{array}{l}-.100 \\
(.055) \\
\end{array}$ \\
\hline $\begin{array}{l}\text { Math test (1995) } \\
\cdot 10^{-2}\end{array}$ & $\cdots$ & $\cdots$ & $\cdots$ & $\begin{array}{l}-.018 \\
(.049) \\
\end{array}$ & $\begin{array}{l}-.012 \\
(.049) \\
\end{array}$ & $\begin{array}{l}-.018 \\
(.049) \\
\end{array}$ & $\begin{array}{l}-.011 \\
(.054) \\
\end{array}$ & $\begin{array}{l}-.013 \\
(.055) \\
\end{array}$ \\
\hline $\mathrm{N}$ & 940 & 940 & 606 & 606 & 606 & 606 & 372 & 372 \\
\hline
\end{tabular}

Estimates of linear probability models are reported. STC information is available in Waves 3-5. 
Table 4: Effects of STC Participation on High School Graduation by Wave 6

\begin{tabular}{|c|c|c|c|c|c|c|c|c|}
\hline & \multicolumn{6}{|c|}{ Sample in any waves with STC information } & \multicolumn{2}{|c|}{$\begin{array}{l}\text { Sample in all waves with } \\
\text { STC information }\end{array}$} \\
\hline & (1) & $(2)$ & $(3)$ & (4) & $(5)$ & (6) & $(7)$ & $(8)$ \\
\hline Mean of dep. var. & \multicolumn{2}{|c|}{.768} & \multicolumn{4}{|c|}{.799} & \multicolumn{2}{|c|}{.832} \\
\hline Any STC & $\begin{aligned} .136 \\
(.030) \\
\end{aligned}$ & $\begin{array}{l}.136 \\
(.029) \\
\end{array}$ & $\begin{array}{l}.138 \\
(.034) \\
\end{array}$ & $\begin{array}{l}.128 \\
(.033)\end{array}$ & .. & $\cdots$ & $\begin{aligned} .138 \\
(.047) \\
\end{aligned}$ & ... \\
\hline Academics Plus & $\ldots$ & $\ldots$ & $\ldots$ & $\ldots$ & $\begin{array}{l}.090 \\
(.091)\end{array}$ & $\cdots$ & $\ldots$ & $\ldots$ \\
\hline College Access & $\cdots$ & $\cdots$ & $\cdots$ & $\cdots$ & $\begin{array}{l}.087 \\
(.033)\end{array}$ & $\cdots$ & $\cdots$ & $\cdots$ \\
\hline PRIME & .. & $\ldots$ & .. & $\ldots$ & $\begin{array}{r}.142 \\
(.075) \\
\end{array}$ & .. & .. & $\ldots$ \\
\hline $\begin{array}{l}\text { Combined small } \\
\text { programs }\end{array}$ & $\cdots$ & $\ldots$ & $\ldots$ & $\ldots$ & $\begin{array}{l}.087 \\
(.132) \\
\end{array}$ & .. & .. & $\ldots$ \\
\hline Other & $\ldots$ & $\cdots$ & $\cdots$ & $\ldots$ & $\begin{array}{l}.083 \\
(.052) \\
\end{array}$ & $\cdots$ & $\cdots$ & $\cdots$ \\
\hline $\begin{array}{l}\text { Test equality of STC } \\
\text { coefficients (p- } \\
\text { value) }\end{array}$ & $\ldots$ & $\ldots$ & $\ldots$ & $\ldots$ & .972 & $\cdots$ & $\ldots$ & $\ldots$ \\
\hline $\begin{array}{l}\text { Number of programs } \\
\text { x years }\end{array}$ & $\ldots$ & $\ldots$ & $\ldots$ & $\ldots$ & $\ldots$ & $\begin{array}{c}.055 \\
(.015)\end{array}$ & $\ldots$ & $\begin{array}{c}.051 \\
(.016)\end{array}$ \\
\hline Female & $\begin{array}{l}.069 \\
(.029)\end{array}$ & $\begin{array}{l}.064 \\
(.029)\end{array}$ & $\begin{array}{c}.044 \\
(.034) \\
\end{array}$ & $\begin{array}{l}.038 \\
(.033)\end{array}$ & $\begin{array}{l}.033 \\
(.033)\end{array}$ & $\begin{array}{l}.041 \\
(.033)\end{array}$ & $\begin{array}{l}.025 \\
(.039)\end{array}$ & $\begin{array}{l}.028 \\
(.039)\end{array}$ \\
\hline Black & $\begin{array}{l}-.054 \\
(.036)\end{array}$ & $\begin{array}{l}-.030 \\
(.038)\end{array}$ & $\begin{array}{l}-.011 \\
(.044) \\
\end{array}$ & $\begin{array}{l}.060 \\
(.045) \\
\end{array}$ & $\begin{array}{r}.058 \\
(.045) \\
\end{array}$ & $\begin{aligned} .064 \\
(.045) \\
\end{aligned}$ & $\begin{array}{l}.104 \\
(.052) \\
\end{array}$ & $\begin{array}{l}.111 \\
(.052) \\
\end{array}$ \\
\hline Latino & $\begin{array}{l}-.180 \\
(.066) \\
\end{array}$ & $\begin{array}{l}-.153 \\
(.066) \\
\end{array}$ & $\begin{array}{l}-.151 \\
(.076) \\
\end{array}$ & $\begin{array}{l}-.091 \\
(.075) \\
\end{array}$ & $\begin{array}{l}-.093 \\
(.076) \\
\end{array}$ & $\begin{array}{l}-.082 \\
(.075) \\
\end{array}$ & $\begin{array}{l}.110 \\
(.116) \\
\end{array}$ & $\begin{array}{l}.128 \\
(.116) \\
\end{array}$ \\
\hline Asian/other & $\begin{array}{l}.072 \\
(.087)\end{array}$ & $\begin{array}{c}.068 \\
(.086)\end{array}$ & $\begin{array}{l}.164 \\
(.100)\end{array}$ & $\begin{array}{l}.153 \\
(.097)\end{array}$ & $\begin{array}{l}.142 \\
(.097)\end{array}$ & $\begin{array}{l}.146 \\
(.097)\end{array}$ & $\begin{array}{l}.112 \\
(.127)\end{array}$ & $\begin{array}{l}.102 \\
(.127)\end{array}$ \\
\hline $\begin{array}{l}\text { Lives with bio } \\
\text { mother only }\end{array}$ & $\ldots$ & $\begin{array}{l}-.021 \\
(.035)\end{array}$ & $\begin{array}{l}.017 \\
(.040)\end{array}$ & $\begin{array}{l}.025 \\
(.040)\end{array}$ & $\begin{array}{l}.018 \\
(.040) \\
\end{array}$ & $\begin{array}{l}.018 \\
(.040)\end{array}$ & $\begin{array}{l}.003 \\
(.046)\end{array}$ & $\begin{array}{l}-.006 \\
(.046)\end{array}$ \\
\hline $\begin{array}{l}\text { Lives with one bio } \\
\text { and one step parent }\end{array}$ & $\ldots$ & $\begin{array}{l}-.099 \\
(.043)\end{array}$ & $\begin{array}{l}-.119 \\
(.051)\end{array}$ & $\begin{array}{l}-.104 \\
(.050)\end{array}$ & $\begin{array}{l}-.104 \\
(.050)\end{array}$ & $\begin{array}{l}-.105 \\
(.050)\end{array}$ & $\begin{array}{l}-.137 \\
(.060)\end{array}$ & $\begin{array}{l}-.139 \\
(.060)\end{array}$ \\
\hline $\begin{array}{l}\text { Other living } \\
\text { arrangement }\end{array}$ & $\ldots$ & $\begin{array}{l}-.170 \\
(.046) \\
\end{array}$ & $\begin{array}{l}-.137 \\
(.053) \\
\end{array}$ & $\begin{array}{l}-.097 \\
(.053) \\
\end{array}$ & $\begin{array}{l}-.108 \\
(.053) \\
\end{array}$ & $\begin{array}{l}-.104 \\
(.053) \\
\end{array}$ & $\begin{array}{l}-.106 \\
(.063)\end{array}$ & $\begin{array}{l}-.120 \\
(.063)\end{array}$ \\
\hline $\begin{array}{l}\text { Only non-missing } \\
\text { test scores }\end{array}$ & & & $\mathrm{X}$ & $\mathrm{X}$ & $\mathrm{X}$ & $\mathrm{X}$ & $\mathrm{X}$ & $\mathrm{X}$ \\
\hline $\begin{array}{l}\text { Reading test (1995) } \\
\cdot 10^{-2}\end{array}$ & $\ldots$ & $\ldots$ & $\ldots$ & $\begin{array}{l}.277 \\
(.076) \\
\end{array}$ & $\begin{array}{l}.280 \\
(.076) \\
\end{array}$ & $\begin{array}{l}.277 \\
(.076) \\
\end{array}$ & $\begin{array}{l}.149 \\
(.092) \\
\end{array}$ & $\begin{array}{l}.157 \\
(.092) \\
\end{array}$ \\
\hline $\begin{array}{l}\text { Math test (1995) } \\
\cdot 10^{-2}\end{array}$ & $\ldots$ & $\ldots$ & $\ldots$ & $\begin{array}{l}.078 \\
(.077) \\
\end{array}$ & $\begin{array}{l}.063 \\
(.077) \\
\end{array}$ & $\begin{array}{l}.075 \\
(.077) \\
\end{array}$ & $\begin{array}{l}.195 \\
(.091) \\
\end{array}$ & $\begin{array}{l}.194 \\
(.091) \\
\end{array}$ \\
\hline $\mathrm{N}$ & 876 & 876 & 567 & 567 & 567 & 567 & 357 & 357 \\
\hline
\end{tabular}

See notes to Table 3 . 
Table 5: Effects of STC Participation on Educational Aspirations at Wave 6

\begin{tabular}{|c|c|c|c|c|c|c|c|c|}
\hline & \multicolumn{6}{|c|}{ Sample in any waves with STC information } & \multicolumn{2}{|c|}{$\begin{array}{l}\text { Sample in all waves with } \\
\text { STC information }\end{array}$} \\
\hline & (1) & (2) & (3) & (4) & (5) & (6) & (7) & (8) \\
\hline Mean of dep. var. & \multicolumn{2}{|c|}{9.24} & \multicolumn{4}{|c|}{9.32} & \multicolumn{2}{|c|}{9.34} \\
\hline Any STC & $\begin{array}{r}.482 \\
(.112) \\
\end{array}$ & $\begin{array}{c}.484 \\
(.112) \\
\end{array}$ & $\begin{array}{c}.473 \\
(.131) \\
\end{array}$ & $\begin{array}{r}.424 \\
(.127) \\
\end{array}$ & $\ldots$ & $\ldots$ & $\begin{array}{r}.289 \\
(.167) \\
\end{array}$ & $\ldots$ \\
\hline Academics Plus & $\ldots$ & $\ldots$ & $\ldots$ & $\ldots$ & $\begin{array}{l}.209 \\
(.347) \\
\end{array}$ & $\ldots$ & $\ldots$ & $\ldots$ \\
\hline College Access & $\ldots$ & $\ldots$ & $\ldots$ & $\ldots$ & $\begin{array}{l}.223 \\
(.126)\end{array}$ & $\cdots$ & .. & $\cdots$ \\
\hline PRIME & .. & $\ldots$ & $\cdots$ & $\ldots$ & $\begin{array}{l}.850 \\
(.283)\end{array}$ & $\cdots$ & & $\cdots$ \\
\hline $\begin{array}{l}\text { Combined small } \\
\text { programs }\end{array}$ & .. & $\cdots$ & $\ldots$ & $\ldots$ & $\begin{array}{l}-.481 \\
(.480)\end{array}$ & $\cdots$ & $\ldots$ & $\cdots$ \\
\hline Other & $\cdots$ & $\cdots$ & $\cdots$ & $\ldots$ & $\begin{array}{l}.680 \\
(.193)\end{array}$ & $\cdots$ & $\cdots$ & $\ldots$ \\
\hline $\begin{array}{l}\text { Test equality of STC } \\
\text { coefficients (p- } \\
\text { value) }\end{array}$ & $\ldots$ & $\ldots$ & $\ldots$ & $\ldots$ & .049 & $\ldots$ & .. & $\ldots$ \\
\hline $\begin{array}{l}\text { Number of programs } \\
x \text { years }\end{array}$ & $\cdots$ & $\cdots$ & $\cdots$ & $\cdots$ & $\ldots$ & $\begin{array}{l}.179 \\
(.055)\end{array}$ & & $\begin{array}{l}.157 \\
(.064)\end{array}$ \\
\hline Female & $\begin{array}{l}.235 \\
(.109)\end{array}$ & $\begin{array}{l}.216 \\
.(109)\end{array}$ & $\begin{array}{l}.033 \\
(.131)\end{array}$ & $\begin{array}{l}-.008 \\
(.127)\end{array}$ & $\begin{array}{l}-.051 \\
(.126)\end{array}$ & $\begin{array}{l}-.008 \\
(.127)\end{array}$ & $\begin{array}{l}-.184 \\
(.162)\end{array}$ & $\begin{array}{l}-.190 \\
(.161)\end{array}$ \\
\hline Black & $\begin{array}{c}.071 \\
(.139) \\
\end{array}$ & $\begin{array}{l}.086 \\
(.144)\end{array}$ & $\begin{array}{l}-.008 \\
(.171)\end{array}$ & $\begin{array}{l}.290 \\
(.175)\end{array}$ & $\begin{array}{r}.257 \\
(.174)\end{array}$ & $\begin{array}{c}.302 \\
(.175)\end{array}$ & $\begin{array}{l}.337 \\
(.218)\end{array}$ & $\begin{array}{r}.307 \\
(.216) \\
\end{array}$ \\
\hline Latino & $\begin{array}{l}.201 \\
(.257) \\
\end{array}$ & $\begin{array}{l}.228 \\
(.260) \\
\end{array}$ & $\begin{array}{l}.215 \\
(.296) \\
\end{array}$ & $\begin{array}{c}.517 \\
(.290) \\
\end{array}$ & $\begin{array}{l}.485 \\
(.288) \\
\end{array}$ & $\begin{array}{c}.541 \\
(.290) \\
\end{array}$ & $\begin{array}{c}.574 \\
(.478) \\
\end{array}$ & $\begin{array}{c}.572 \\
(.473) \\
\end{array}$ \\
\hline Asian/other & $\begin{array}{l}.655 \\
(.328)\end{array}$ & $\begin{array}{l}.648 \\
(.329)\end{array}$ & $\begin{array}{l}.350 \\
(.388)\end{array}$ & $\begin{array}{l}.306 \\
(.375)\end{array}$ & $\begin{array}{l}.226 \\
(.372)\end{array}$ & $\begin{array}{l}.280 \\
(.375)\end{array}$ & $\begin{array}{l}-.259 \\
(.525)\end{array}$ & $\begin{array}{l}-.283 \\
(.523)\end{array}$ \\
\hline $\begin{array}{l}\text { Lives with bio } \\
\text { mother only }\end{array}$ & $\ldots$ & $\begin{array}{l}.019 \\
(.133)\end{array}$ & $\begin{array}{l}.018 \\
(.156)\end{array}$ & $\begin{array}{l}.057 \\
(.150)\end{array}$ & $\begin{array}{l}.020 \\
(.150)\end{array}$ & $\begin{array}{l}-.034 \\
(.150)\end{array}$ & $\begin{array}{l}-.019 \\
(.190)\end{array}$ & $\begin{array}{l}-.042 \\
(.189)\end{array}$ \\
\hline $\begin{array}{l}\text { Lives with one bio } \\
\text { and one step parent }\end{array}$ & $\ldots$ & $\begin{array}{l}-.096 \\
(.165)\end{array}$ & $\begin{array}{l}-.195 \\
(.197)\end{array}$ & $\begin{array}{l}-.118 \\
(.190)\end{array}$ & $\begin{array}{l}-.117 \\
(.189)\end{array}$ & $\begin{array}{l}-.110 \\
(.190)\end{array}$ & $\begin{array}{l}-.117 \\
(.245)\end{array}$ & $\begin{array}{l}-.114 \\
(.244)\end{array}$ \\
\hline $\begin{array}{l}\text { Other living } \\
\text { arrangement }\end{array}$ & $\ldots$ & $\begin{array}{l}-.228 \\
(.177) \\
\end{array}$ & $\begin{array}{l}-.252 \\
(.209) \\
\end{array}$ & $\begin{array}{l}-.088 \\
(.204)\end{array}$ & $\begin{array}{l}-.153 \\
(.203) \\
\end{array}$ & $\begin{array}{l}-.110 \\
(.204) \\
\end{array}$ & $\begin{array}{l}-.126 \\
(.262) \\
\end{array}$ & $\begin{array}{l}-.168 \\
(.261) \\
\end{array}$ \\
\hline $\begin{array}{l}\text { Only non-missing } \\
\text { test scores }\end{array}$ & & & $\mathrm{X}$ & $\mathrm{X}$ & $\mathrm{X}$ & $\mathrm{X}$ & $\mathrm{X}$ & $\mathrm{X}$ \\
\hline $\begin{array}{l}\text { Reading test (1995) } \\
\cdot 10^{-2}\end{array}$ & .. & $\cdots$ & $\cdots$ & $\begin{array}{l}1.57 \\
(.29)\end{array}$ & $\begin{array}{l}1.57 \\
(.29)\end{array}$ & $\begin{array}{l}1.57 \\
(.29)\end{array}$ & $\begin{array}{l}2.07 \\
(.38)\end{array}$ & $\begin{array}{l}2.08 \\
(.38)\end{array}$ \\
\hline $\begin{array}{l}\text { Math test (1995) } \\
\cdot 10^{-2}\end{array}$ & $\cdots$ & ... & $\cdots$ & $\begin{array}{l}-.096 \\
(.292) \\
\end{array}$ & $\begin{array}{l}.175 \\
(.291) \\
\end{array}$ & $\begin{array}{l}-.094 \\
(.292)\end{array}$ & $\begin{array}{l}-.355 \\
(.370) \\
\end{array}$ & $\begin{array}{l}.372 \\
(.369) \\
\end{array}$ \\
\hline $\mathrm{N}$ & 891 & 891 & 577 & 577 & 577 & 577 & 359 & 359 \\
\hline
\end{tabular}

Educational aspirations are coded as: $1-8^{\text {th }}$ or less, $2-9^{\text {th }}-11^{\text {th }}, 3$-technical training with high school degree, 4GED, 5-graduate from high school, 6-post-high school vocational or technical training, 7-some college, 8degree from two-year college, 9-degree from four-year college, 10-Master's degree, 11-law, Ph.D, or M.D. Estimates are from linear regressions. 
Table 6: Effects of STC Participation on Educational Goals, Aspirations, and Expectations at Wave 6

\begin{tabular}{|c|c|c|c|c|c|c|c|c|c|c|c|c|}
\hline & \multicolumn{2}{|c|}{$\begin{array}{l}\text { Disappointment } \\
\text { if do not graduate } \\
\text { from college }\end{array}$} & \multicolumn{2}{|c|}{$\begin{array}{l}\text { Lowest level of } \\
\text { education with } \\
\text { which satisfied }\end{array}$} & \multicolumn{2}{|c|}{$\begin{array}{l}\text { Lowest level of } \\
\text { education with } \\
\text { which satisfied } \\
\text { 4-year college }\end{array}$} & \multicolumn{2}{|c|}{$\begin{array}{c}\text { Educational } \\
\text { aspirations 4-year } \\
\text { college or higher }\end{array}$} & \multicolumn{2}{|c|}{$\begin{array}{l}\text { Educational } \\
\text { expectations }\end{array}$} & \multicolumn{2}{|c|}{$\begin{array}{c}\text { Educational } \\
\text { expectations 4- } \\
\text { year college or } \\
\text { higher }\end{array}$} \\
\hline & $(1)$ & $\left(1^{\prime}\right)$ & $(2)$ & $\left(2^{\prime}\right)$ & (3) & $\left(3^{\prime}\right)$ & (4) & $\left(4^{\prime}\right)$ & $(5)$ & $\left(5^{\prime}\right)$ & $(6)$ & $\left(6^{\prime}\right)$ \\
\hline Mean of dep. var. & \multicolumn{2}{|c|}{4.04} & \multicolumn{2}{|c|}{7.40} & \multicolumn{2}{|c|}{.464} & \multicolumn{2}{|c|}{.832} & \multicolumn{2}{|c|}{8.98} & \multicolumn{2}{|c|}{.753} \\
\hline Any STC & $\begin{array}{l}.184 \\
(.117)\end{array}$ & $\ldots$ & $\begin{array}{l}.501 \\
(.180)\end{array}$ & $\ldots$ & $\begin{array}{l}.124 \\
(.041)\end{array}$ & $\ldots$ & $\begin{array}{l}.072 \\
(.032)\end{array}$ & $\ldots$ & $\begin{array}{l}.400 \\
(.130)\end{array}$ & $\ldots$ & $\begin{array}{l}.106 \\
(.037)\end{array}$ & $\ldots$ \\
\hline $\begin{array}{l}\text { Number of } \\
\text { programs x years }\end{array}$ & $\ldots$ & $\begin{array}{l}.146 \\
(.050)\end{array}$ & $\ldots$ & $\begin{array}{l}.239 \\
(.077)\end{array}$ & $\ldots$ & $\begin{array}{l}.064 \\
(.018)\end{array}$ & $\ldots$ & $\begin{array}{c}.032 \\
(.014)\end{array}$ & $\ldots$ & $\begin{array}{l}.177 \\
(.056)\end{array}$ & $\ldots$ & $\begin{array}{c}.051 \\
(.016)\end{array}$ \\
\hline $\mathrm{N}$ & 603 & 603 & 571 & 571 & 571 & 571 & 577 & 577 & 556 & 556 & 556 & 556 \\
\hline
\end{tabular}

Sample includes those in any waves with STC information. All specifications include controls for demographics, family structure, and test scores. In columns (1) and (1'), coding is 1-5, from not too disappointed to very disappointed. For coding in columns (2)-(2') and (5)-(5') see notes to Table 5. Estimates are from linear regressions/linear probability models. Note that in contrast to the estimates in Table 5, column (5), for all of the dependent variables in this table equality of the coefficients of the disaggregated STC programs is never rejected at the 10-percent level. 
Table 7: Effects of STC Participation on Attending 4-Year College at Wave 6, for Graduates

\begin{tabular}{|c|c|c|c|c|c|c|c|c|}
\hline & \multicolumn{6}{|c|}{ Sample in any waves with STC information } & \multicolumn{2}{|c|}{$\begin{array}{l}\text { Sample in all waves with } \\
\text { STC information }\end{array}$} \\
\hline & (1) & $(2)$ & $(3)$ & $(4)$ & $(5)$ & (6) & $(7)$ & $(8)$ \\
\hline Mean of dep. var. & \multicolumn{2}{|c|}{.378} & \multicolumn{4}{|c|}{.400} & \multicolumn{2}{|c|}{.431} \\
\hline Any STC & $\begin{array}{l}.100 \\
(.040)\end{array}$ & $\begin{array}{l}.101 \\
(.040)\end{array}$ & $\begin{array}{l}.108 \\
(.049)\end{array}$ & $\begin{array}{l}.112 \\
(.046)\end{array}$ & .. & ... & $\begin{array}{l}.111 \\
(.059)\end{array}$ & $\cdots$ \\
\hline Academics Plus & $\ldots$ & $\ldots$ & $\ldots$ & $\ldots$ & $\begin{array}{l}-.072 \\
(.111)\end{array}$ & $\cdots$ & $\ldots$ & $\cdots$ \\
\hline College Access & $\ldots$ & $\cdots$ & $\cdots$ & $\cdots$ & $\begin{array}{l}.123 \\
(.045)\end{array}$ & $\cdots$ & $\cdots$ & $\cdots$ \\
\hline PRIME & $\cdots$ & $\cdots$ & $\cdots$ & $\cdots$ & $\begin{array}{l}.160 \\
(.093)\end{array}$ & $\cdots$ & $\cdots$ & $\cdots$ \\
\hline $\begin{array}{l}\text { Combined small } \\
\text { programs }\end{array}$ & $\cdots$ & $\cdots$ & $\cdots$ & $\cdots$ & $\begin{array}{l}.122 \\
(.165)\end{array}$ & $\cdots$ & $\cdots$ & $\cdots$ \\
\hline Other & $\cdots$ & $\cdots$ & $\cdots$ & $\cdots$ & $\begin{array}{l}.102 \\
(.065)\end{array}$ & $\cdots$ & $\cdots$ & $\cdots$ \\
\hline $\begin{array}{l}\text { Test equality of STC } \\
\text { coefficients (p- } \\
\text { value) }\end{array}$ & $\cdots$ & $\cdots$ & $\cdots$ & $\ldots$ & .547 & $\cdots$ & $\cdots$ & $\cdots$ \\
\hline $\begin{array}{l}\text { Number of programs } \\
\mathrm{x} \text { years }\end{array}$ & $\cdots$ & $\cdots$ & $\cdots$ & $\cdots$ & $\cdots$ & $\begin{array}{c}.077 \\
(.019) \\
\end{array}$ & $\cdots$ & $\begin{aligned} .073 \\
(.022) \\
\end{aligned}$ \\
\hline Female & $\begin{array}{l}.088 \\
(.039)\end{array}$ & $\begin{array}{l}.095 \\
(.039)\end{array}$ & $\begin{array}{l}.117 \\
(.047)\end{array}$ & $\begin{array}{l}.108 \\
(.045)\end{array}$ & $\begin{array}{l}.099 \\
(.045)\end{array}$ & $\begin{array}{l}.108 \\
(.045)\end{array}$ & $\begin{array}{l}.060 \\
(.056)\end{array}$ & $\begin{array}{l}.058 \\
(.055)\end{array}$ \\
\hline Black & $\begin{array}{l}-.080 \\
(.048) \\
\end{array}$ & $\begin{array}{l}-.036 \\
(.051) \\
\end{array}$ & $\begin{array}{l}-.066 \\
(.062)\end{array}$ & $\begin{array}{l}.083 \\
(.062) \\
\end{array}$ & $\begin{array}{l}.062 \\
(.063)\end{array}$ & $\begin{array}{l}.065 \\
(.062) \\
\end{array}$ & $\begin{array}{l}.108 \\
(.076) \\
\end{array}$ & $\begin{array}{c}.083 \\
(.075) \\
\end{array}$ \\
\hline Latino & $\begin{array}{l}.051 \\
(.095) \\
\end{array}$ & $\begin{array}{l}.072 \\
(.095) \\
\end{array}$ & $\begin{array}{l}.167 \\
(.116) \\
\end{array}$ & $\begin{array}{l}.254 \\
(.110) \\
\end{array}$ & $\begin{array}{l}.227 \\
(.110) \\
\end{array}$ & $\begin{array}{l}.250 \\
(.108)\end{array}$ & $\begin{array}{l}.413 \\
(.173) \\
\end{array}$ & $\begin{array}{l}.390 \\
(.170)\end{array}$ \\
\hline Asian/other & $\begin{array}{l}.278 \\
(.113)\end{array}$ & $\begin{array}{l}.275 \\
(.112)\end{array}$ & $\begin{array}{l}.231 \\
(.128)\end{array}$ & $\begin{array}{l}.239 \\
(.121)\end{array}$ & $\begin{array}{l}.232 \\
(.120)\end{array}$ & $\begin{array}{l}.228 \\
(.119)\end{array}$ & $\begin{array}{l}.162 \\
(.172)\end{array}$ & $\begin{array}{l}.150 \\
(.170)\end{array}$ \\
\hline $\begin{array}{l}\text { Lives with bio } \\
\text { mother only }\end{array}$ & $\ldots$ & $\begin{array}{l}-.113 \\
(.046) \\
\end{array}$ & $\begin{array}{l}-.116 \\
(.056) \\
\end{array}$ & $\begin{array}{l}-.097 \\
(.053) \\
\end{array}$ & $\begin{array}{l}-.099 \\
(.053) \\
\end{array}$ & $\begin{array}{l}-.103 \\
(.052)\end{array}$ & $\begin{array}{l}-.114 \\
(.066)\end{array}$ & $\begin{array}{l}-.120 \\
(.064)\end{array}$ \\
\hline $\begin{array}{l}\text { Lives with one bio } \\
\text { and one step parent }\end{array}$ & $\cdots$ & $\begin{array}{l}-.055 \\
(.059)\end{array}$ & $\begin{array}{l}-.070 \\
(.075)\end{array}$ & $\begin{array}{l}-.057 \\
(.071)\end{array}$ & $\begin{array}{l}-.058 \\
(.071)\end{array}$ & $\begin{array}{l}-.055 \\
(.070)\end{array}$ & $\begin{array}{l}-.030 \\
(.088)\end{array}$ & $\begin{array}{l}-.031 \\
(.087)\end{array}$ \\
\hline $\begin{array}{l}\text { Other living } \\
\text { arrangement }\end{array}$ & $\cdots$ & $\begin{array}{l}-.136 \\
(.066) \\
\end{array}$ & $\begin{array}{l}-.140 \\
(.079) \\
\end{array}$ & $\begin{array}{l}-.091 \\
(.075) \\
\end{array}$ & $\begin{array}{l}-.108 \\
(.075) \\
\end{array}$ & $\begin{array}{l}-.104 \\
(.074) \\
\end{array}$ & $\begin{array}{l}-.124 \\
(.092) \\
\end{array}$ & $\begin{array}{l}-.146 \\
(.091) \\
\end{array}$ \\
\hline $\begin{array}{l}\text { Only non-missing } \\
\text { test scores }\end{array}$ & & & $\mathrm{X}$ & $\mathrm{X}$ & $\mathrm{X}$ & $\mathrm{X}$ & $\mathrm{X}$ & $\mathrm{X}$ \\
\hline $\begin{array}{l}\text { Reading test (1995) } \\
\cdot 10^{-2}\end{array}$ & $\cdots$ & $\cdots$ & $\cdots$ & $\begin{array}{c}.444 \\
(.108) \\
\end{array}$ & $\begin{array}{l}.458 \\
(.108) \\
\end{array}$ & $\begin{array}{l}.448 \\
(.106)\end{array}$ & $\begin{array}{l}.578 \\
(.132) \\
\end{array}$ & $\begin{array}{l}.587 \\
(.131) \\
\end{array}$ \\
\hline $\begin{array}{l}\text { Math test (1995) } \\
\cdot 10^{-2}\end{array}$ & $\cdots$ & $\cdots$ & $\ldots$ & $\begin{array}{l}.242 \\
(.106) \\
\end{array}$ & $\begin{array}{l}.209 \\
(.106) \\
\end{array}$ & $\begin{array}{l}.229 \\
(.104) \\
\end{array}$ & $\begin{array}{l}.179 \\
(.132) \\
\end{array}$ & $\begin{array}{l}.158 \\
(.130) \\
\end{array}$ \\
\hline $\mathrm{N}$ & 650 & 650 & 438 & 438 & 438 & 438 & 290 & 290 \\
\hline
\end{tabular}

See notes to Table 3. Estimates are from linear probability models. 
Table 8: Effects of STC Participation on College Attendance, for Graduates

\begin{tabular}{|c|c|c|c|c|c|c|c|c|}
\hline & \multicolumn{2}{|c|}{ Attend college } & \multicolumn{2}{|c|}{$\begin{array}{l}\text { Attend 4-year } \\
\text { college } \\
\text { conditional on } \\
\text { college } \\
\text { attendance }\end{array}$} & \multicolumn{2}{|c|}{$\begin{array}{c}\text { Full-time college } \\
\text { attendance }\end{array}$} & \multicolumn{2}{|c|}{$\begin{array}{l}\text { Full-time college } \\
\text { attendance } \\
\text { conditional on } \\
\text { college attendance }\end{array}$} \\
\hline & (1) & $\left(1^{\prime}\right)$ & (2) & $\left(2^{\prime}\right)$ & (3) & $\left(3^{\prime}\right)$ & (4) & $\left(4^{\prime}\right)$ \\
\hline Mean of dep. var. & \multicolumn{2}{|c|}{.616} & \multicolumn{2}{|c|}{.639} & \multicolumn{2}{|c|}{.561} & \multicolumn{2}{|c|}{.892} \\
\hline Any STC & $\begin{array}{r}.096 \\
(.046)\end{array}$ & $\cdots$ & $\begin{array}{l}.095 \\
(.061)\end{array}$ & $\ldots$ & $\begin{array}{l}.111 \\
(.046)\end{array}$ & .. & $\begin{array}{c}.051 \\
(.040)\end{array}$ & $\ldots$ \\
\hline $\begin{array}{l}\text { Number of programs } \\
\text { x years }\end{array}$ & $\ldots$ & $\begin{array}{l}.040 \\
(.019)\end{array}$ & $\ldots$ & $\begin{array}{l}.088 \\
(.024)\end{array}$ & $\cdots$ & $\begin{array}{c}.054 \\
(.019)\end{array}$ & $\cdots$ & $\begin{array}{l}.035 \\
(.016)\end{array}$ \\
\hline $\mathrm{N}$ & 443 & 443 & 274 & 274 & 442 & 442 & 278 & 278 \\
\hline
\end{tabular}

"College attendance" includes college, university, or technical school. Sample includes those in any waves with STC information. All specifications include controls for demographics, family structure, and test scores. Estimates are from linear probability models. 
Table 9: Descriptive Statistics on STC Participation and Wave 1 Educational Expectations, Attitudes, and Aspirations

\begin{tabular}{|l|c|c|c|c|}
\hline & $\begin{array}{c}\text { Disappointment if } \\
\text { do not graduate } \\
\text { from college }\end{array}$ & $\begin{array}{c}\text { Have to do well in } \\
\text { school to be successful } \\
\text { in life }\end{array}$ & $\begin{array}{c}\text { Chance will } \\
\text { graduate high } \\
\text { school by age 25 }\end{array}$ & $\begin{array}{c}\text { Chance will } \\
\text { graduate college by } \\
\text { age 25 }\end{array}$ \\
\hline Any STC $(\mathrm{N}=332)$ & $(1)$ & $(2)$ & $(3)$ & $(4)$ \\
\hline No STC $(\mathrm{N}=314)$ & 4.41 & 1.18 & 2.80 & 2.63 \\
& $(1.21)$ & $(.40)$ & $(.46)$ & $(.56)$ \\
\hline
\end{tabular}

Means are reported, with standard deviations in parentheses. Sample is restricted to observations with STC information in any of Waves 3-5, and information on all of the education expectations, etc., questions. Educational aspirations are coded as: 1-no school, $2-8^{\text {th }}$ or less, $3-9^{\text {th }}-11^{\text {th }}, 4$-graduate from high school, 5-post-high school vocational or technical training, 6-some college, 7-degree from two-year college, 8-degree from four-year college, 9-Master's degree, 10-law, Ph.D, or M.D. Disappointment if fails to graduate from college is coded as 1-5, from not too disappointed to very disappointed. Have to do well in school to be successful is coded as: 1-strongly agree, 2-agree, 3-disagree, and 4-strongly disagree. Chances of graduation are coded as: 1-low, 2-middle, and 3-high. 
Table 10: Effects of STC Participation on Schooling-Related Outcomes, Controlling for Wave 1 Educational Expectations, Attitudes, and Aspirations

\begin{tabular}{|c|c|c|c|c|c|}
\hline & Dropout & $\begin{array}{c}\text { Graduate high } \\
\text { school }\end{array}$ & $\begin{array}{c}\text { Educational } \\
\text { aspirations }\end{array}$ & $\begin{array}{l}\text { College } \\
\text { attendance }\end{array}$ & $\begin{array}{l}\text { 4-year college } \\
\text { attendance }\end{array}$ \\
\hline & (1) & (2) & (3) & (4) & (5) \\
\hline \multicolumn{6}{|l|}{$\begin{array}{l}\text { Without wave } 1 \\
\text { controls: }\end{array}$} \\
\hline Any STC & $\begin{array}{l}-.061 \\
(.022)\end{array}$ & $\begin{array}{l}.139 \\
(.035)\end{array}$ & $\begin{array}{l}.449 \\
(.131)\end{array}$ & $\begin{array}{l}.082 \\
(.048)\end{array}$ & $\begin{array}{l}.105 \\
(.048)\end{array}$ \\
\hline \multicolumn{6}{|l|}{$\begin{array}{l}\text { With wave } 1 \\
\text { controls: }\end{array}$} \\
\hline Any STC & $\begin{array}{l}-.057 \\
(.022) \\
\end{array}$ & $\begin{array}{l}.133 \\
(.035) \\
\end{array}$ & $\begin{array}{r}.398 \\
(.128) \\
\end{array}$ & $\begin{array}{c}.082 \\
(.048) \\
\end{array}$ & $\begin{array}{l}.096 \\
(.048) \\
\end{array}$ \\
\hline $\begin{array}{l}\text { Disappointment if } \\
\text { do not graduate from } \\
\text { college }\end{array}$ & $\begin{array}{c}.012 \\
(.009)\end{array}$ & $\begin{array}{l}-.029 \\
(.015)\end{array}$ & $\begin{array}{l}.128 \\
(.055)\end{array}$ & $\begin{array}{l}-.018 \\
(.020)\end{array}$ & $\begin{array}{c}.038 \\
(.020)\end{array}$ \\
\hline $\begin{array}{l}\text { Have to do well in } \\
\text { school to be } \\
\text { successful in life }\end{array}$ & $\begin{array}{l}.021 \\
(.024)\end{array}$ & $\begin{array}{l}-.063 \\
(.036)\end{array}$ & $\begin{array}{l}-.172 \\
(.135)\end{array}$ & $\begin{array}{l}.032 \\
(.054)\end{array}$ & $\begin{array}{l}.085 \\
(.054)\end{array}$ \\
\hline $\begin{array}{l}\text { Chance will } \\
\text { graduate high school } \\
\text { by age } 25\end{array}$ & $\begin{array}{l}.065 \\
(.024)\end{array}$ & $\begin{array}{c}.110 \\
(.037)\end{array}$ & $\begin{array}{c}.461 \\
(.140)\end{array}$ & $\begin{array}{c}.102 \\
(.058)\end{array}$ & $\begin{array}{c}.090 \\
(.058)\end{array}$ \\
\hline $\begin{array}{l}\text { Chance will } \\
\text { graduate college by } \\
\text { age } 25\end{array}$ & $\begin{array}{l}-.002 \\
(.022)\end{array}$ & $\begin{array}{l}.005 \\
(.033)\end{array}$ & $\begin{array}{l}.097 \\
(.124)\end{array}$ & $\begin{array}{l}-.050 \\
(.046)\end{array}$ & $\begin{array}{l}-.030 \\
(.046)\end{array}$ \\
\hline $\mathrm{N}$ & 529 & 497 & 503 & 394 & 389 \\
\hline
\end{tabular}

Sample includes those in any waves with STC information, and with Wave 1 information as explained in notes to Table 9; also see notes to that table for coding of Wave 1 variables. All specifications include controls for demographics, family structure, and test scores. The results-including the signs of the Wave 1 controls (and the rough magnitudes) — were generally similar when they were entered one at a time in separate specifications. 
Table 11: Effects of STC Participation on Schooling-Related Outcomes, Controlling for Type of School and Allowing Different Effects by Type of School

\begin{tabular}{|c|c|c|c|c|c|}
\hline & Dropout & $\begin{array}{c}\text { Graduate high } \\
\text { school }\end{array}$ & $\begin{array}{c}\text { Educational } \\
\text { aspirations }\end{array}$ & $\begin{array}{c}\text { College } \\
\text { attendance }\end{array}$ & $\begin{array}{l}\text { 4-year college } \\
\text { attendance }\end{array}$ \\
\hline & $(1)$ & $(2)$ & (3) & (4) & $(5)$ \\
\hline \multicolumn{6}{|l|}{$\begin{array}{l}\text { Previous } \\
\text { specifications: }\end{array}$} \\
\hline Any STC & $\begin{array}{l}-.061 \\
(.021)\end{array}$ & $\begin{array}{l}.128 \\
(.033)\end{array}$ & $\begin{array}{l}.424 \\
(.127)\end{array}$ & $\begin{array}{l}.096 \\
(.046)\end{array}$ & $\begin{array}{l}.112 \\
(.046)\end{array}$ \\
\hline \multicolumn{6}{|l|}{$\begin{array}{l}\text { With type of school } \\
\text { controls: }\end{array}$} \\
\hline Any STC & $\begin{array}{l}-.067 \\
(.022)\end{array}$ & $\begin{array}{l}.135 \\
(.034)\end{array}$ & $\begin{array}{l}.469 \\
(.129)\end{array}$ & $\begin{array}{l}.089 \\
(.047)\end{array}$ & $\begin{array}{l}.106 \\
(.046)\end{array}$ \\
\hline Magnet school & $\begin{array}{l}-.075 \\
(.031)\end{array}$ & $\begin{array}{l}.122 \\
(.048)\end{array}$ & $\begin{array}{l}.486 \\
(.186)\end{array}$ & $\begin{array}{l}.077 \\
(.061)\end{array}$ & $\begin{array}{l}.177 \\
(.060)\end{array}$ \\
\hline Vocational school & $\begin{array}{c}-.024 \\
(.034) \\
\end{array}$ & $\begin{array}{l}-.006 \\
(.054)\end{array}$ & $\begin{array}{l}.182 \\
(.206)\end{array}$ & $\begin{array}{l}-.110 \\
(.076)\end{array}$ & $\begin{array}{l}-.169 \\
(.076)\end{array}$ \\
\hline \multicolumn{6}{|l|}{$\begin{array}{l}\text { With type of school } \\
\text { controls and } \\
\text { differential effects } \\
\text { by type of school: }\end{array}$} \\
\hline Any STC & $\begin{array}{l}-.087 \\
(.025)\end{array}$ & $\begin{array}{l}.157 \\
(.039)\end{array}$ & $\begin{array}{l}.463 \\
(.148)\end{array}$ & $\begin{array}{l}.095 \\
(.056)\end{array}$ & $\begin{array}{l}.134 \\
(.055)\end{array}$ \\
\hline Magnet school & $\begin{array}{l}-.117 \\
(.042)\end{array}$ & $\begin{array}{l}.146 \\
(.065)\end{array}$ & $\begin{array}{l}.713 \\
(.250)\end{array}$ & $\begin{array}{l}.160 \\
(.086)\end{array}$ & $\begin{array}{l}.258 \\
(.085)\end{array}$ \\
\hline Vocational school & $\begin{array}{l}-.051 \\
(.045)\end{array}$ & $\begin{array}{l}.054 \\
(.070)\end{array}$ & $\begin{array}{l}-.128 \\
(.266)\end{array}$ & $\begin{array}{l}-.218 \\
(.098)\end{array}$ & $\begin{array}{l}-.176 \\
(.097)\end{array}$ \\
\hline $\begin{array}{l}\text { Any STC x magnet } \\
\text { school }\end{array}$ & $\begin{array}{l}.085 \\
(.057)\end{array}$ & $\begin{array}{l}-.043 \\
(.088)\end{array}$ & $\begin{array}{l}-.482 \\
(.340)\end{array}$ & $\begin{array}{l}-.161 \\
(.111)\end{array}$ & $\begin{array}{l}-.152 \\
(.110)\end{array}$ \\
\hline $\begin{array}{l}\text { Any STC x } \\
\text { vocational school }\end{array}$ & $\begin{array}{l}.058 \\
(.069)\end{array}$ & $\begin{array}{l}-.150 \\
(.111)\end{array}$ & $\begin{array}{l}.811 \\
(.414)\end{array}$ & $\begin{array}{l}.273 \\
(.154)\end{array}$ & $\begin{array}{l}.045 \\
(.155)\end{array}$ \\
\hline $\begin{array}{l}\text { Test equality of STC } \\
\text { coefficients (p- } \\
\text { value) }\end{array}$ & .277 & .384 & .033 & .043 & .336 \\
\hline $\mathrm{N}$ & 606 & 567 & 577 & 443 & 438 \\
\hline
\end{tabular}

Sample includes those in any waves with STC information. All specifications include controls for demographics, family structure, and test scores. 
Table 12: Effects of STC Participation on Schooling-Related Outcomes, At-Risk vs. Others

\begin{tabular}{|c|c|c|c|c|c|}
\hline & Dropout & $\begin{array}{c}\text { Graduate high } \\
\text { school }\end{array}$ & $\begin{array}{c}\text { Educational } \\
\text { aspirations }\end{array}$ & $\begin{array}{c}\text { College } \\
\text { attendance }\end{array}$ & $\begin{array}{l}\text { 4-year college } \\
\text { attendance }\end{array}$ \\
\hline & (1) & $(2)$ & (3) & (4) & $(5)$ \\
\hline \multicolumn{6}{|l|}{$\begin{array}{l}\text { Non-nuclear } \\
\text { family: }\end{array}$} \\
\hline Any STC & $\begin{array}{l}-.023 \\
(.035) \\
\end{array}$ & $\begin{array}{l}.092 \\
(.054)\end{array}$ & $\begin{array}{l}.519 \\
(.208)\end{array}$ & $\begin{array}{l}.075 \\
(.072)\end{array}$ & $\begin{array}{l}.140 \\
(.072)\end{array}$ \\
\hline $\begin{array}{l}\text { Any STC x non- } \\
\text { nuclear family }\end{array}$ & $\begin{array}{l}-.059 \\
(.043)\end{array}$ & $\begin{array}{l}.056 \\
(.067)\end{array}$ & $\begin{array}{l}-.149 \\
(.258)\end{array}$ & $\begin{array}{l}.035 \\
(.092)\end{array}$ & $\begin{array}{l}-.045 \\
(.092)\end{array}$ \\
\hline $\mathrm{N}$ & 606 & 567 & 577 & 443 & 438 \\
\hline \multicolumn{6}{|l|}{$\begin{array}{l}\text { Math scores below } \\
\text { median: }\end{array}$} \\
\hline Any STC & $\begin{array}{l}-.068 \\
(.026)\end{array}$ & $\begin{array}{l}.104 \\
(.040)\end{array}$ & $\begin{array}{l}.332 \\
(.154)\end{array}$ & $\begin{array}{l}.054 \\
(.053)\end{array}$ & $\begin{array}{l}.065 \\
(.053)\end{array}$ \\
\hline $\begin{array}{l}\text { Any STC x low } \\
\text { math scores }\end{array}$ & $\begin{array}{l}.016 \\
(.036)\end{array}$ & $\begin{array}{l}.060 \\
(.056)\end{array}$ & $\begin{array}{l}.228 \\
(.215)\end{array}$ & $\begin{array}{l}.120 \\
(.076)\end{array}$ & $\begin{array}{l}.133 \\
(.076)\end{array}$ \\
\hline $\mathrm{N}$ & 606 & 567 & 577 & 443 & 438 \\
\hline \multicolumn{6}{|l|}{$\begin{array}{l}\text { Reading scores } \\
\text { below median: }\end{array}$} \\
\hline Any STC & $\begin{array}{l}-.044 \\
(.026) \\
\end{array}$ & $\begin{array}{l}.109 \\
(.040) \\
\end{array}$ & $\begin{aligned} .476 \\
(.153) \\
\end{aligned}$ & $\begin{array}{l}.114 \\
(.052) \\
\end{array}$ & $\begin{array}{l}.104 \\
(.052) \\
\end{array}$ \\
\hline $\begin{array}{l}\text { Any STC x low } \\
\text { reading scores }\end{array}$ & $\begin{array}{l}-.042 \\
(.035)\end{array}$ & $\begin{array}{l}.049 \\
(.055)\end{array}$ & $\begin{array}{l}-.130 \\
(.211)\end{array}$ & $\begin{array}{l}-.053 \\
(.076)\end{array}$ & $\begin{array}{c}.024 \\
(.076)\end{array}$ \\
\hline $\mathrm{N}$ & 606 & 567 & 577 & 443 & 438 \\
\hline \multicolumn{6}{|l|}{$\begin{array}{l}\text { Aspires to less than } \\
\text { 4-year college: }\end{array}$} \\
\hline Any STC & $\begin{array}{l}-.022 \\
(.024)\end{array}$ & $\begin{array}{l}.112 \\
(.039) \\
\end{array}$ & $\begin{array}{l}.352 \\
(.140)\end{array}$ & $\begin{array}{l}.051 \\
(.054)\end{array}$ & $\begin{array}{l}.073 \\
(.055)\end{array}$ \\
\hline $\begin{array}{l}\text { Any STC x low } \\
\text { aspirations }\end{array}$ & $\begin{array}{l}-.166 \\
(.061)\end{array}$ & $\begin{array}{l}.141 \\
(.101)\end{array}$ & $\begin{array}{l}.137 \\
(.370)\end{array}$ & $\begin{array}{l}-.002 \\
(.156)\end{array}$ & $\begin{array}{l}.025 \\
(.158)\end{array}$ \\
\hline $\mathrm{N}$ & 483 & 452 & 463 & 358 & 353 \\
\hline \multicolumn{6}{|l|}{$\begin{array}{l}\text { Mother's education } \\
\text { high school or less: }\end{array}$} \\
\hline Any STC & $\begin{array}{l}-.069 \\
(.039) \\
\end{array}$ & $\begin{array}{l}.138 \\
(.060) \\
\end{array}$ & $\begin{array}{l}-.079 \\
(.219) \\
\end{array}$ & $\begin{array}{l}-.071 \\
(.080) \\
\end{array}$ & $\begin{array}{l}-.031 \\
(.081) \\
\end{array}$ \\
\hline $\begin{array}{l}\text { Any STC x low } \\
\text { mother's education }\end{array}$ & $\begin{array}{l}.021 \\
(.049)\end{array}$ & $\begin{array}{l}.004 \\
(.076)\end{array}$ & $\begin{array}{l}.578 \\
(.277)\end{array}$ & $\begin{array}{l}.237 \\
(.105)\end{array}$ & $\begin{array}{l}.222 \\
(.106)\end{array}$ \\
\hline $\mathrm{N}$ & 416 & 388 & 399 & 315 & 311 \\
\hline
\end{tabular}

Sample includes those in any waves with STC information. All specifications include controls for demographics, family structure, and test scores, as well as for the main effect for the new interaction if it is not already included (such as the indicator for low mother's education). The mean for the low mother's education indicator is about 0.6. The educational aspirations and mother's education data are available in Wave 1 . See notes to corresponding tables for more details. 
Appendix Table A1: Observations by Wave and File in the PELS

\begin{tabular}{|c|c|c|c|c|c|c|}
\hline & W1 & W2 & W3 & W4 & W5 & W6 \\
\hline Total & 1470 & 1332 & 1561 & 1447 & 1280 & 1169 \\
\hline In W1 & $\ldots$ & 1111 & 1031 & 915 & 818 & 742 \\
\hline Not in W1 & $\ldots$ & 221 & 530 & 532 & 462 & 427 \\
\hline In W2 & $\ldots$ & $\ldots$ & 1045 & 903 & 806 & 719 \\
\hline Not in W2 & $\ldots$ & $\ldots$ & 516 & 544 & 474 & 450 \\
\hline In W3 & $\ldots$ & $\ldots$ & $\ldots$ & 1160 & 1000 & 878 \\
\hline Not in W3 & $\ldots$ & $\ldots$ & $\ldots$ & 287 & 280 & 291 \\
\hline In W4 & $\ldots$ & $\ldots$ & $\ldots$ & $\ldots$ & 1016 & 873 \\
\hline Not in W4 & $\ldots$ & $\ldots$ & $\ldots$ & $\ldots$ & 264 & 296 \\
\hline In W5 & $\ldots$ & $\ldots$ & $\ldots$ & $\ldots$ & $\ldots$ & 854 \\
\hline Not in W5 & $\ldots$ & $\ldots$ & $\ldots$ & $\ldots$ & $\ldots$ & 315 \\
\hline In no previous waves & & 221 & 368 & 137 & 68 & 13 \\
\hline In all previous waves & $\ldots$ & 1111 & 883 & 691 & 537 & 378 \\
\hline $\begin{array}{l}\text { In W3, W4, or W5 (some } \\
\text { STC info) }\end{array}$ & $\ldots$ & $\ldots$ & $\ldots$ & $\ldots$ & $\ldots$ & 1097 \\
\hline \begin{tabular}{l|l} 
Also in \\
administrative file \\
(non-missing test \\
scores)
\end{tabular} & & & & & & 639 \\
\hline $\begin{array}{l}\text { In W3, W4, and W5 } \\
\text { (complete STC info) }\end{array}$ & $\ldots$ & $\ldots$ & $\ldots$ & $\ldots$ & $\ldots$ & 601 \\
\hline \begin{tabular}{l|l} 
Also in \\
administrative file \\
(non-missing test \\
scores)
\end{tabular} & & & & & & 387 \\
\hline
\end{tabular}

The highlighted entries in the last column give the sizes of the potential analysis samples with and without test scores, and requiring that respondents be interviewed in any or all of Waves 3-5, when the STC questions were asked. The actual samples analyzed are smaller because of missing data on other variables. 
Appendix Table A2: Descriptive Statistics for STC Participation

\begin{tabular}{|c|c|c|c|c|}
\hline & \multicolumn{2}{|c|}{$\begin{array}{l}\text { Sample in any wave } \\
\text { with STC information }\end{array}$} & \multicolumn{2}{|c|}{$\begin{array}{c}\text { Sample in all waves } \\
\text { with STC information }\end{array}$} \\
\hline & Total & In W6 & Total & In W6 \\
\hline \# of observations & 1676 & 940 & 823 & 572 \\
\hline \multicolumn{5}{|l|}{ By program: } \\
\hline Academics Plus & .033 & .031 & .040 & .033 \\
\hline ASPIRA & .004 & .004 & .002 & .003 \\
\hline College Access & .449 & .485 & .530 & .544 \\
\hline Laser & .001 & .001 & .001 & .002 \\
\hline Legacy & .004 & .003 & .005 & .005 \\
\hline Philadelphia Futures & .005 & .004 & .006 & .005 \\
\hline PRIME & .042 & .051 & .056 & .066 \\
\hline Say Yes to Education & .001 & .002 & .001 & .002 \\
\hline Upward Bound & .004 & .001 & .005 & .002 \\
\hline White-Williams Scholars & .011 & .012 & .017 & .014 \\
\hline Other & .087 & .101 & .112 & .110 \\
\hline \multicolumn{5}{|l|}{ Total: } \\
\hline Any STC participation & .519 & .553 & .604 & .614 \\
\hline $\begin{array}{l}\text { Number of programs } \\
\text { (x years) }\end{array}$ & .896 & 1.006 & 1.198 & 1.229 \\
\hline $\begin{array}{l}\text { Number of programs } \\
\text { (x years) for participants }\end{array}$ & 1.744 & 1.819 & 1.984 & 2.003 \\
\hline \multicolumn{5}{|l|}{ By year: } \\
\hline Any STC participation, W3 & .346 & .353 & .352 & .361 \\
\hline Any STC participation, W4 & .231 & .262 & .315 & .325 \\
\hline Any STC participation, W5 & .243 & .299 & .372 & .383 \\
\hline
\end{tabular}

STC information is reported in Waves 3-5. Sample for any STC participation in Wave 3 is smaller because some respondents report being in grade 8 in Wave 3, in which case STC data are treated as missing. Sample proportions or means are reported. Sample also excludes those with missing or contradictory information on race, ethnicity, or sex, and those who report dropping out in Waves 3-5. 
Appendix Table A3: Effects of STC Participation on Other High School Behaviors/Achievements

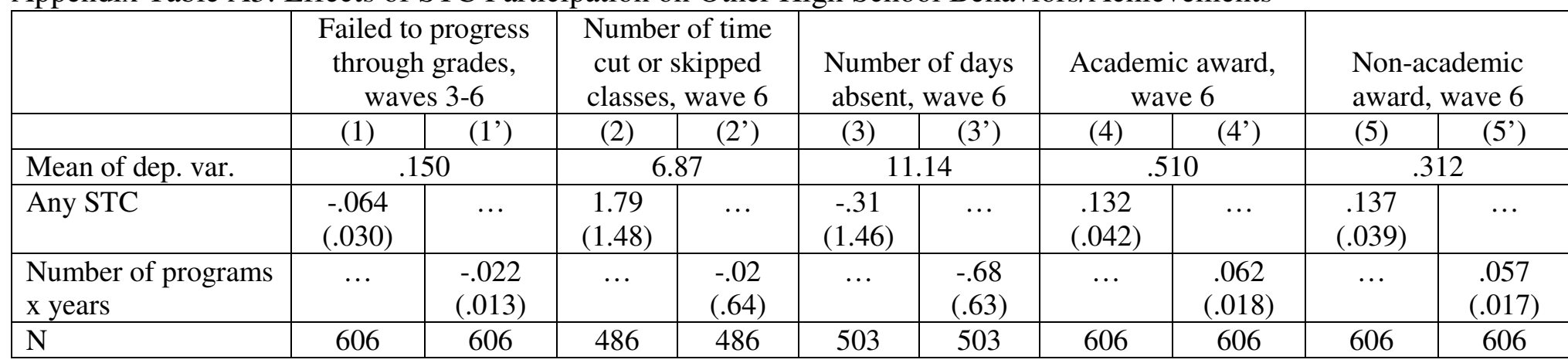

Sample includes those in any waves with STC information. All specifications include controls for demographics, family structure, and test scores. Failure to progress is defined as failure to move to a higher grade in each year for which data are available; it can include dropping out. Academic awards include academic honor, award in science or math fair, special recognition for good grades or honor roll, or special recognition for writing an essay or poem. Non-academic awards include elected officer of a school class, named most valuable player on a sports team, community service award, or award in technical or skills competition. Estimates are from linear regressions/linear probability models. 
Appendix Table A4: Effects of STC Participation on Schooling-Related Outcomes, by Sex

\begin{tabular}{|l|c|c|c|c|c|}
\hline & Dropout & $\begin{array}{c}\text { Graduate high } \\
\text { school }\end{array}$ & $\begin{array}{c}\text { Educational } \\
\text { aspirations }\end{array}$ & $\begin{array}{c}\text { College } \\
\text { attendance }\end{array}$ & $\begin{array}{c}\text { 4-year college } \\
\text { attendance }\end{array}$ \\
\hline Females: & $(1)$ & $(2)$ & $(3)$ & $(4)$ & $(5)$ \\
\hline Any STC & & & & & \\
\hline $\mathrm{N}$ & -.059 & .100 & .436 & .123 & .128 \\
\hline Males: & 3648 & $(.041)$ & $(.169)$ & $(.058)$ & $(.061)$ \\
\hline Any STC & & 337 & 349 & 271 & 267 \\
\hline $\mathrm{N}$ & -.075 & .187 & & & \\
\hline Test of equality of & $.034)$ & $(.056)$ & $(.195)$ & .105 & .104 \\
$\begin{array}{l}\text { STC coefficients for } \\
\text { males and females } \\
\text { (p-values) }\end{array}$ & .733 & 230 & 228 & 172 & $1.074)$ \\
\hline
\end{tabular}

Models are estimated separately by sex. Sample includes those in any waves with STC information. All specifications include controls for demographics, family structure, and test scores. See notes to corresponding tables for more details. The test of equality is from a regression pooling observations for males and females but adding an interaction of STC participation with gender; the p-value reported is for the test of significance of this interaction. 
Appendix Table A5: Predictors of Attrition

\begin{tabular}{|c|c|c|c|c|c|}
\hline & (1) & $(2)$ & (3) & (4) & (5) \\
\hline Any STC & $\begin{array}{l}-.126 \\
(.044) \\
\end{array}$ & $\begin{array}{l}-.054 \\
(.045) \\
\end{array}$ & $\begin{array}{l}-.050 \\
(.031) \\
\end{array}$ & $\begin{array}{l}-.082 \\
(.026) \\
\end{array}$ & $\begin{array}{l}-.142 \\
(.059) \\
\end{array}$ \\
\hline Female & $\begin{array}{l}-.116 \\
(.031) \\
\end{array}$ & $\begin{array}{l}-.094 \\
(.024) \\
\end{array}$ & $\begin{array}{l}-.084 \\
(.027) \\
\end{array}$ & $\begin{array}{l}-.088 \\
(.024) \\
\end{array}$ & $\begin{array}{l}-.106 \\
(.036) \\
\end{array}$ \\
\hline Black & $\begin{array}{l}.000 \\
(.042)\end{array}$ & $\begin{array}{l}.004 \\
(.033)\end{array}$ & $\begin{array}{l}.003 \\
(.035)\end{array}$ & $\begin{array}{l}.009 \\
(.032) \\
\end{array}$ & $\begin{array}{l}.002 \\
(.041)\end{array}$ \\
\hline Latino & $\begin{array}{l}.042 \\
(.067)\end{array}$ & $\begin{array}{l}.071 \\
(.054)\end{array}$ & $\begin{array}{l}.027 \\
(.063)\end{array}$ & $\begin{array}{l}.074 \\
(.054)\end{array}$ & $\begin{array}{l}.026 \\
(.067)\end{array}$ \\
\hline Asian/other & $\begin{aligned} .018 \\
(.093) \\
\end{aligned}$ & $\begin{array}{l}.006 \\
(.075) \\
\end{array}$ & $\begin{array}{l}-.023 \\
(.094) \\
\end{array}$ & $\begin{array}{c}.013 \\
(.075) \\
\end{array}$ & $\begin{array}{r}.004 \\
(.092) \\
\end{array}$ \\
\hline $\begin{array}{l}\text { Lives with bio } \\
\text { mother only }\end{array}$ & $\begin{array}{l}.074 \\
(.038) \\
\end{array}$ & $\begin{array}{l}.080 \\
(.043) \\
\end{array}$ & $\begin{array}{l}.007 \\
(.033) \\
\end{array}$ & $\begin{array}{r}.053 \\
(.031) \\
\end{array}$ & $\begin{array}{r}.050 \\
(.053) \\
\end{array}$ \\
\hline $\begin{array}{l}\text { Lives with one bio } \\
\text { and one step parent }\end{array}$ & $\begin{array}{l}.106 \\
(.046)\end{array}$ & $\begin{array}{l}.157 \\
(.051)\end{array}$ & $\begin{array}{l}.101 \\
(.040)\end{array}$ & $\begin{array}{l}.122 \\
(.036)\end{array}$ & $\begin{array}{l}.141 \\
(.065)\end{array}$ \\
\hline $\begin{array}{l}\text { Other living } \\
\text { arrangement }\end{array}$ & $\begin{array}{l}.125 \\
(.049) \\
\end{array}$ & $\begin{array}{l}.129 \\
(.056) \\
\end{array}$ & $\begin{array}{l}.056 \\
(.043) \\
\end{array}$ & $\begin{array}{l}.105 \\
(.039) \\
\end{array}$ & $\begin{array}{r}.144 \\
(.071) \\
\end{array}$ \\
\hline $\begin{array}{l}\text { Reading test below } \\
\text { median }\end{array}$ & $\begin{array}{l}.062 \\
(.049)\end{array}$ & $\ldots$ & $\ldots$ & $\ldots$ & $\begin{array}{c}.061 \\
(.049)\end{array}$ \\
\hline $\begin{array}{l}\text { Math test below } \\
\text { median }\end{array}$ & $\begin{array}{l}-.047 \\
(.050) \\
\end{array}$ & $\ldots$ & $\ldots$ & $\ldots$ & $\begin{array}{l}-.039 \\
(.050) \\
\end{array}$ \\
\hline $\begin{array}{l}\text { Held back grades 3- } \\
5\end{array}$ & $\ldots$ & $\ldots$ & $\begin{array}{l}-.035 \\
(.050) \\
\end{array}$ & $\ldots$ & $\begin{array}{l}.211 \\
(.066)\end{array}$ \\
\hline $\begin{array}{l}\text { Dropout by wave } 6 \\
\text { (administrative data) }\end{array}$ & $\ldots$ & $\ldots$ & $\ldots$ & $\begin{array}{l}.136 \\
(.053) \\
\end{array}$ & $\begin{array}{l}.144 \\
(.071) \\
\end{array}$ \\
\hline $\begin{array}{l}\text { Reading test below } \\
\text { median } \cdot \text { Any STC }\end{array}$ & $\begin{array}{l}-.071 \\
(.068) \\
\end{array}$ & $\ldots$ & $\ldots$ & $\ldots$ & $\begin{array}{l}-.084 \\
(.068) \\
\end{array}$ \\
\hline $\begin{array}{l}\text { Math test below } \\
\text { median } \cdot \text { Any STC }\end{array}$ & $\begin{array}{l}-.047 \\
(.050)\end{array}$ & $\ldots$ & $\ldots$ & $\ldots$ & $\begin{array}{l}.123 \\
(.068)\end{array}$ \\
\hline $\begin{array}{l}\text { Lives with bio } \\
\text { mother only } \cdot \text { Any } \\
\text { STC }\end{array}$ & $\ldots$ & $\begin{array}{l}-.035 \\
(.059)\end{array}$ & $\ldots$ & $\ldots$ & $\begin{array}{l}.020 \\
(.073)\end{array}$ \\
\hline $\begin{array}{l}\text { Lives with one bio } \\
\text { and one step parent } \\
\text { Any STC }\end{array}$ & $\ldots$ & $\begin{array}{l}-.060 \\
(.071)\end{array}$ & $\ldots$ & $\ldots$ & $\begin{array}{l}-.076 \\
(.090)\end{array}$ \\
\hline $\begin{array}{l}\text { Other living } \\
\text { arrangement } \cdot \text { Any } \\
\text { STC }\end{array}$ & $\cdots$ & $\begin{array}{l}-.031 \\
(.077)\end{array}$ & $\cdots$ & $\ldots$ & $\begin{array}{l}-.034 \\
(.096)\end{array}$ \\
\hline $\begin{array}{l}\text { Held back grades } 3- \\
5 \cdot \text { Any STC }\end{array}$ & $\ldots$ & $\ldots$ & $\begin{array}{l}.171 \\
(.073) \\
\end{array}$ & $\ldots$ & $\begin{array}{c}.291 \\
(.096) \\
\end{array}$ \\
\hline $\begin{array}{l}\text { Dropout by wave } 6 \cdot \\
\text { Any STC }\end{array}$ & $\ldots$ & $\ldots$ & $\ldots$ & $\begin{array}{r}.049 \\
(.081) \\
\end{array}$ & $\begin{array}{r}.094 \\
(.114) \\
\end{array}$ \\
\hline $\mathrm{N}$ & 1062 & 1675 & 1299 & 1675 & 1062 \\
\hline
\end{tabular}

Sample is restricted to those in any of Waves 3-5. Estimates are from linear probability models. 
Appendix Table A6: Effects of STC Participation Reweighting to Correct for Attrition Bias

\begin{tabular}{|c|c|c|c|c|}
\hline & Dropout & $\begin{array}{c}\text { Graduate high } \\
\text { school }\end{array}$ & $\begin{array}{c}\text { Educational } \\
\text { aspirations }\end{array}$ & $\begin{array}{l}\text { 4-year college } \\
\text { attendance }\end{array}$ \\
\hline & (1) & $(2)$ & (3) & $(5)$ \\
\hline \multicolumn{5}{|l|}{ Uncorrected: } \\
\hline Any STC & $\begin{array}{l}-.061 \\
(.021) \\
\end{array}$ & $\begin{array}{l}.128 \\
(.033) \\
\end{array}$ & $\begin{array}{r}.424 \\
(.127) \\
\end{array}$ & $\begin{array}{l}.112 \\
(.046) \\
\end{array}$ \\
\hline \multicolumn{5}{|l|}{$\begin{array}{l}\text { Reweight based on } \\
\text { estimates in Appendix } \\
\text { Table A4, column (5): }\end{array}$} \\
\hline Any STC & $\begin{array}{l}-.061 \\
(.023)\end{array}$ & $\begin{array}{l}.117 \\
(.035)\end{array}$ & $\begin{array}{c}.414 \\
(.128) \\
\end{array}$ & $\begin{array}{l}.105 \\
(.045) \\
\end{array}$ \\
\hline \multicolumn{5}{|l|}{$\begin{array}{l}\text { Reweight based on } \\
\text { estimates in Appendix } \\
\text { Table A4, column (4): }\end{array}$} \\
\hline Any STC & $\begin{array}{l}-.059 \\
(.022) \\
\end{array}$ & $\begin{array}{l}.120 \\
(.034) \\
\end{array}$ & $\begin{array}{c}.398 \\
(.128) \\
\end{array}$ & $\begin{array}{l}.106 \\
(.045) \\
\end{array}$ \\
\hline $\mathrm{N}$ & 606 & 567 & 577 & 438 \\
\hline
\end{tabular}

Sample includes those in any waves with STC information. All specifications include controls for demographics, and family structure. Estimates are from linear probability models, with observations weighted by the inverse of one minus the predicted attrition rate for the individual based on estimates in columns (4) and (5) of Appendix Table A5. The uncorrected estimates in the first row are from earlier tables. 